\title{
Ice dynamics of union glacier from SAR offset tracking
}

Gomez, Rodrigo; Arigony-Neto, Jorge; De Santis, Angela; Vijay, Saurabh; Jaña, Ricardo; Rivera, Andres

Published in:

Global and Planetary Change

Link to article, DOI:

10.1016/j.gloplacha.2018.12.012

Publication date:

2019

Document Version

Peer reviewed version

Link back to DTU Orbit

Citation (APA):

Gomez, R., Arigony-Neto, J., De Santis, A., Vijay, S., Jaña, R., \& Rivera, A. (2019). Ice dynamics of union glacier from SAR offset tracking. Global and Planetary Change, 174, 1-15.

https://doi.org/10.1016/j.gloplacha.2018.12.012

\section{General rights}

Copyright and moral rights for the publications made accessible in the public portal are retained by the authors and/or other copyright owners and it is a condition of accessing publications that users recognise and abide by the legal requirements associated with these rights.

- Users may download and print one copy of any publication from the public portal for the purpose of private study or research.

- You may not further distribute the material or use it for any profit-making activity or commercial gain

- You may freely distribute the URL identifying the publication in the public portal 


\section{Accepted Manuscript}

Ice dynamics of union glacier from SAR offset tracking

Rodrigo Gomez, Jorge Arigony-Neto, Angela De Santis, Saurabh Vijay, Ricardo Jaña, Andres Rivera

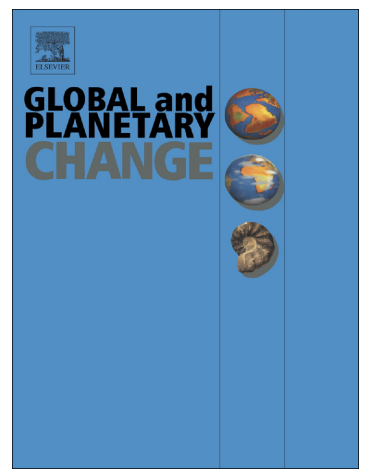

PII:

S0921-8181(18)30224-8

DOI: https://doi.org/10.1016/j.gloplacha.2018.12.012

Reference:

GLOBAL 2884

To appear in:

Global and Planetary Change

Received date: $\quad 14$ April 2018

Revised date: $\quad 22$ December 2018

Accepted date: $\quad 26$ December 2018

Please cite this article as: Rodrigo Gomez, Jorge Arigony-Neto, Angela De Santis, Saurabh Vijay, Ricardo Jaña, Andres Rivera, Ice dynamics of union glacier from SAR offset tracking. Global (2018), https://doi.org/10.1016/j.gloplacha.2018.12.012

This is a PDF file of an unedited manuscript that has been accepted for publication. As a service to our customers we are providing this early version of the manuscript. The manuscript will undergo copyediting, typesetting, and review of the resulting proof before it is published in its final form. Please note that during the production process errors may be discovered which could affect the content, and all legal disclaimers that apply to the journal pertain. 


\section{Ice dynamics of Union glacier from SAR offset tracking}

Rodrigo Gomez ${ }^{\text {a,b, }}{ }^{2}$ rgome zfell egmail .com, Jorge Arigony-Neto ${ }^{\text {a,c }}$

jorgearigonyefurg.br, Angela De Santis ${ }^{\text {b,d }}$, Saurabh Vijay ${ }^{\mathrm{e}}$, Ricardo Jaña ${ }^{\mathrm{f}}$, Andres Rivera ${ }^{\text {g,h }}$

${ }^{a}$ Instituto de Oceanografia, Universidade Federal do Rio Grande (FURG), Rio Grande, Brazil

${ }^{\mathrm{b}}$ Centro Regional Fundacion CEQUA, Punta Arenas, Chile

${ }^{\mathrm{c}}$ Instituto Nacional de Ciência e Tecnologia da Criosfera, Porto Alegre, Brazil

${ }^{\mathrm{d}}$ HOPE (Humanitarian Operations), Bruxelles (Belgium)

${ }^{e}$ DTU Space (National Space Institute), Technical University of Denmark, Copenhagen, Denmark

${ }^{\mathrm{f}}$ Instituto Antartico Chileno, Punta Arenas, Chile

${ }^{g}$ Centro de Estudios Cient' ficos, P.O. Box 5110466, Valdivia, Chile

${ }^{\mathrm{h}}$ Departamento de Geografa, Universidad de Chile, Santiago, Chile

*Corresponding author.

\section{Abstract}

The Antarctic ice sheet is predicted to be the major contributor to sea-level rise during the XXI century. Therefore, monitoring ice dynamics of outlet glaciers in Antarctica is of great importance to assess future sea-level rise predictions. Union Glacier is one of the major outlet glaciers of the Ellsworth Mountains and drains into the Ronne-Filchner Ice Shelf. Glaciers can be studied using remote-sensing techniques, which combined with field measurements can deliver a good approximation of its dynamics and can be used as input for glacier models. In this study we acquired high resolution Stripmap HIMAGE SAR images from the COSMO-SkyMed satellite constellation during austral summer of 2011-2012, and applied a SAR offset tracking algorithm to compute ice velocities. Then, we compared our derived velocities with field data already published. Results showed mean values of ice velocity estimated for the main trunk of the glacier are $0.043(0.0393 \mathrm{SD}) \mathrm{m} \mathrm{d}^{-1}$, with values reaching up to $0.325 \mathrm{~m} \mathrm{~d}^{-1}$, in agreement with previous studies. A model of ice thickness based on lamellar flow theory is proposed, using estimated surface ice velocity in combination with surface slope derived from TanDEM-X as input data. Comparison of our modeled ice thickness with radar data agree with a mean absolute deviation of $19.22 \%$. From surface ice velocities we computed principal strain rates in order to assess crevasse formation and closure. Thereafter, using high resolution COSMO-SkyMed 
Spotlight-2 SAR images we establish a relation between surface features and acting strain components.

Keywords: Glaciology, Union Glacier Antarctica, Glacier Ice Dynamics, SAR Offset Tracking, Ice Thickness, Glacier Strain Rate

\section{Introduction}

Glacier masses act as water reservoirs, altering the level of oceans and consequently changing continental coast lines. Glaciated masses of Greenland and Antarctic are bound to be the principal contributors to sea level rise in the XXI century, mainly due to accelerated mass loss (Rignot et al., 2011b). Their contribution will be more important than ice caps, mountain glaciers or thermal expansion of the oceans (Cazenave et al., 2008; Dutton et al., 2015).

Antarctic Ice Sheet (AIS) is the world's largest fresh water reservoir with an area of 13.5 million $\mathrm{km}^{2}$ and a volume of 25.4 million $\mathrm{km}^{3}$ (Benn et al., 2010), it is divided in East and West by the Transantarctic Mountains, Eastern Antarctica Ice Sheet being larger in extent than West Antarctic Ice Sheet (WAIS), with precipitation and ablation regimes being different in this two areas (Turner et al., 2014).

One of the biggest concerns about Antarctica is the collapse of ice shelves around the continent (Rignot et al., 2004; Scambos et al., 2004; Rignot et al., 2013; Hellmer et al., 2017) and marine ice shelf instability (MISI) of the WAIS (Rignot and Jacobs, 2002; Nicholls et al., 2009; Ross et al., 2012; Purkey and Johnson, 2013). Bamber et al. (2009) estimated that the mass loss of only WAIS due to MISI has the potential to contribute $3.3 \mathrm{~m}$ of sea-level rise.

The two main mechanisms that dominate glacier mass loss over the Antarctic continent are basal melt and ice front calving (Depoorter et al., 2013; Rignot et al., 2013; Pauling et al., 2016). These processes when accelerated are considered as the prime reasons for reduced buttressing and increased glacier flow, affecting glacier ice dynamics (Rignot et al., 2011b, 2013; Schmidtko et al., 2014).

Surface ice velocities obtained with satellite remote sensing are a valuable tool to assess ice dynamics over remote and vast environments (eg., Morlighem et al. 2011; Fitzpatrick et al. 2013; Osmanoglu et al. 2014). In this study, we calculate a high resolution surface ice velocity field for Union glacier in order to model ice thickness and study surface strain rates over the glacier.

Accurate estimates of ice thickness are hard to obtain. Methods based on airborne or 
ground penetrating radar and active seismology are excellent tools to get field measures. However, they are normally constrained to a small area or they are quite expensive. On the other hand, modeling based on remote-sensing derived variables can approximate ice thickness with high accuracy (eg., Farinotti et al. 2013; Gantayat et al. 2014; Farinotti et al. 2017). This is specially true if glacier thickness field data is available, giving the possibility of accurate model calibration (Farinotti et al., 2009). We follow lamellar flow theory to model ice thickness of Union Glacier (Gantayat et al., 2014), combined with ground penetrating radar (GPR) data for calibration and validation.

Strain rates can be computed from ice surface velocity data derived from satellite remote sensing (eg., Young and Hyland 2002; Rankl et al. 2017). They had been used to assess ice shelf stability and fracture (Rankl et al., 2017), study spatial distribution of transverse and longitudinal strain rates over ice shelves (Young and Hyland, 2002), find a relation between moulins, crevasses and altitude (Poinar et al., 2015) or for calculate tensile stresses for identification of surface crevassed areas (LeDoux et al., 2017). In this study we use strain rates in order to relate them to crevasse formation and ice flow dynamics over the surface of the glacier.

Using surface ice velocities obtained by remote-sensing techniques, we model ice thickness and strain rates; in order to understand Union glacier ice dynamics, its driving factors and implications on glacier surface features.

\section{Study Area}

Union Glacier is located in the Western Antarctic Ice Sheet, in the southern part of the Ellsworth Mountains, Heritage Range area (79 46' S, $\left.8324^{\prime} \mathrm{W}\right)$. It is one of the major outlet glaciers of the Heritage Range and its basin drains into the Constellation Inlet, part of the Ronne-Filchner Ice Shelf (Figure 1).

Ronne-Filchner Ice Shelf is located south of the Weddell Sea, east of the Antarctic Peninsula, and is composed of two separated areas: the Filchner sector to the east and the Ronne sector to the west and closer to the Antarctic Peninsula. It is the second biggest ice shelf of Antarctica ( $443140 \mathrm{~km}^{2}$ ). The platform is loosing $115.4 \pm 45 \mathrm{Gt} \mathrm{a}^{-1} \pm 45$ via basal melting (Rignot et al., 2013) and there is concern about the potential collapse of the platform because of warming of the oceans during the XXI century (Hellmer et al., 2012, 2017). 
Union Glacier has a total length of $86 \mathrm{~km}$ from the Institute Ice Stream divide to its grounding line at Constellation Inlet, with an estimated surface area of $2561 \mathrm{~km}^{2}$ (Rivera et al, 2010). The glacier valley is oriented southwest - northeast with several smaller glacier tributaries draining into it. There is a narrow cross-section ( $7 \mathrm{~km}$ wide) or flux gate, where mass flowing from the plateau and Schanz Glacier has to go through (Rivera et al., 2014b).

There are two heavily crevassed areas along the main trunk, first when Schanz glacier joins with the main Union trunk (Figure 1) and a second one $41 \mathrm{~km}$ from the grounding line associated with a change in relief. This crevasse field was mapped in detail with GPR in Figure 31.8 of Rivera et al. (2014a). Other crevassed areas are along the sides of the fastest flowing part of the glacier.

Union glacier also has an extensive Blue Ice Area (BIA)

Figure 1: Union glacier basin with the footprints of SAR images used in the study. Green and blue polygons show the geographical coverages of Cosmo-SkyMED Stripmap and Spotlight data, respectively. Three small rectangles, indicated as 1,2 and 3, highlight the map extents where principal strain rates were analyzed. Background image is a Landsat-8 scene in true color RGB (432) (figure 8, 9 and 10).

\section{Methods and Data}

In this section we present the methods for extraction of surface ice displacement, generation of an ice thickness model based on lamellar flow and calculation of principal axes surface strain rates derived from ice velocities. The data was obtained from two different satellite missions, Constellation of small Satellites for Mediterranean basin Observation (Cosmo-SkyMED) of the Italian Aerospace Agency (ASI) and TerraSAR-X add-on for Digital Elevation Measurement (TanDEM-X) from the German Aerospace Center (DLR).

\subsection{Satellite Imagery}

Between December 2011 and January 2012 four high resolution Stripmap HIMAGE ( 5 m spatial resolution) and 2 Spotlight-2 (1 m spatial resolution) Cosmo-SkyMED images were acquired (Table 1). Cosmo-SkyMED is a constellation of four satellites launched by the ASI. Each satellite has a microwave high resolution synthetic aperture radar (SAR) X-band sensor operating 
at $9.6 \mathrm{GHz}$, with right and left looking capabilities and a complete orbit cycle of 16 days. They retrieve data in three different acquisition modes Spotlight $\left(10 \mathrm{~km}^{2}\right.$ area coverage and $1 \mathrm{~m}$ spatial resolution), Stripmap (HIMAGE $30 \mathrm{~km}^{2}$ area coverage and $5 \mathrm{~m}$ spatial resolution) and ScanSAR ( $200 \mathrm{~km}^{2}$ area coverage and $100 \mathrm{~m}$ spatial resolution). In this study, we used Stripmap HIMAGE data for surface ice velocity calculations and Spotlight-2 for glacier feature descriptions associated with surface strain rates.

TanDEM- $X$ is a German radar mission launched by the DLR consisting of twin satellites carrying X-band sensor with a prime objective of generating a high accuracy world DEM. TanDEM-X DEM has a vertical accuracy of $10 \mathrm{~m}$ and relative vertical accuracy of $2 \mathrm{~m}$ with a spatial resolution of $0.4 " \times 0.4 "(12.35 \mathrm{~m} \times 12.35 \mathrm{~m})$ at the equator (Krieger et al., 2007).

Table 1: Cosmo-SkyMED SAR images used in this study.

\begin{tabular}{lllllll}
\hline Mode & Acquisition & Polarization & Pass & CSK-Satellite Incidence & Look Dir. \\
& Date & & & Angle & \\
\hline Stripmap & $21 / 12 / 2011$ & VV & Descending & 3 & 24.11 deg. & Right \\
Stripmap & $14 / 01 / 2012$ & VV & Descending & 1 & 24.01 deg. & Right \\
Stripmap & $22 / 01 / 2012$ & VV & Descending & 2 & 24.01 deg. & Right \\
Stripmap & $30 / 01 / 2012$ & VV & Descending & 1 & 24.07 deg. & Right \\
Spotlight-2 & $14 / 07 / 2011$ & HH & Descending & 4 & 22.49 deg. & Right \\
Spotlight-2 & $13 / 07 / 2011$ & VV & Descending & 2 & 22.41 deg. & Right \\
\hline
\end{tabular}

\subsection{Surface Ice Velocities}

We carried out an offset tracking procedure implemented by GAMMA software, in order to estimate surface ice displacements and velocities (Werner et al., 2000), other possible approaches are InS AR (Joughin, 2002) or D-InSAR (Sánchez-Gámez and Navarro, 2017). Offset tracking has been used in several surface ice velocity studies (eg., Ciappa et al. 2010; Muto and Furuya 2013; Riveros et al. 2013; Falk et al. 2016; Satyabala 2016). The algorithm is based on normalized cross-correlation of detected intensity values of a pair of SAR images in slant-range and azimuth geometry (Wegmuller et al., 1998; Werner et al., 2000; Strozzi et al., 2002). The algorithm correlates image intensity patches (Table 2 ) between a master and a slave image where 
the maximum two-dimension cross-correlation function refers to the image offsets (Strozzi et al., 2002). This correlation is carried out in slant-range/azimuth geometry. Signal to noise ratio (SNR) of the height of the correlation peak relative to the average level of the correlation function is established as a quality control of the offsets (Strozzi et al., 2002). We set the SNR threshold at 4.0 as recommended by previous studies (Vijay and Braun, 2017; Rankl et al., 2017). Offset results are then multi-looked and terrain corrected with high resolution Tandem-X World DEM (Wegmuller et al., 1998; Strozzi et al., 2002). The results obtained from the algorithm are magnitude, ground-range and azimuth components of the velocities (e.g., velocities magnitude shown on Figure 4).

The main uncertainties in the surface velocity measurements can be associated with errors on the co-registration or related to the tracking algorithm. We follow a method, used by McNabb et al. (2012); Rankl et al. (2017); Vijay and Braun (2017), for the calculation of the uncertainties associated with the offset tracking procedure denoted as $e_{t}$ at equation 1.

$$
e_{t}=\frac{C \Delta x}{z \Delta t},
$$

Where $C$ is the error associated with the tracking algorithm (in pixels), $\Delta x$ pixel resolution in ground range $(12 \mathrm{~m}), z$ would be the oversampling factor (we used a factor of 5 that approximately recreates a square pixel and is the multi-looking factor used) and $\Delta t$ time amidst acquisitions. Results of $e_{t}$ for each pair are presented in table 2. Errors associated with image co-registration were calculated by estimating RMSE velocity over stable ground (table 2).

Table 2: Offset tracking parameter settings and error estimations

\begin{tabular}{llllllll}
\hline Pair & Master & Slave & $\begin{array}{c}\text { Patch } \\
\text { Size }^{\mathrm{a}}\end{array}$ & $\begin{array}{l}\text { Patch SizeStep } \\
(m)^{\mathrm{b}}\end{array}$ & Interval & RSME & $e_{t}$ \\
\hline Pair1 & $14 / 01 / 201$ & $30 / 01 / 201$ & $256 \times 256$ & $250 \times 479$ & $5 / 5$ & $16 \mathrm{~d}$ & $0.03 \mathrm{~m} \mathrm{~d}^{-1} 0.07 \mathrm{~m} \mathrm{~d}^{-1}$ \\
& 2 & 2 & & & & \\
Pair2 & $21 / 12 / 201$ & $22 / 01 / 201$ & $512 \times 512$ & $499 \times 958$ & $30 / 30$ & $32 \mathrm{~d}$ & $0.01 \mathrm{~m} \mathrm{~d}^{-1} 0.03 \mathrm{~m} \mathrm{~d}^{-1}$ \\
& 1 & 2 & & & & \\
\hline
\end{tabular}

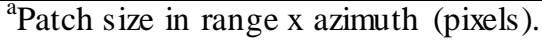

${ }^{\mathrm{b}}$ In meters approximately.

${ }^{\mathrm{c}} \mathrm{Step}$ in range/azimuth (pixels).
} 


\subsection{Ice Thickness}

Bedmap-2 is a state of the art ice thickness model for the AIS (Fretwell et al., 2013). It has some differences with measured data over the area of Heritage range at Ellsworth mountains (Rivera et al., 2010, 2014b). Modeling ice thickness over mountain areas in Antarctica is of vital importance to obtain better estimates of ice volume. We used a method that has been tested for glaciers in the Himalayas and the Alps (Gantayat et al., 2014; Farinotti et al., 2017) and it is based on the assumption of laminar flow (equation 2) (Nye, 1952b; Cuffey and Paterson, 2010; Van der Veen, 2013).

$$
U_{s}=U_{b}+\frac{2 A}{n+1} \tau_{b}^{n} H
$$

Where $U_{s}$ refers as the surface velocity, $U_{b}$ as the basal velocity, $A$ is the flow parameter, which is assumed to be $3.5 \times 10^{-25} \mathrm{~s}^{-1} \mathrm{~Pa}^{-3}$ for ice at $-10^{\circ} \mathrm{C}$ (Cuffey and Paterson, 2010), $n$ is Glen's law exponential parameter set to 3 (Cuffey and Paterson, 2010), $\tau_{b}$ is basal drag and $H$ ice thickness. Some assumptions are needed to be made. First, basal velocity is set to $U_{b}=0$, based on Rivera et al. (2010). We can use the following relation $\tau_{b}=f \tau_{d}$ (Cuffey and Paterson, 2010), were $\tau_{d}$ is the driving stress and $f$ is defined as the shape factor related to the geometry of the valley, in this way a connection between basal and driving stresses can be made. Normally, $f$ is considered between $[0-1]$, where 1 is infinite wide and 0 is infinite depth (Nye, 1965; Van der Veen, 2013). The shape factor can be calculated either by the center line velocities or by the balance forces acting on the glacier. Nye (1965) gives values of $f$ for different shapes using the center line method, where for a half width of $3.5 \mathrm{~km}$ and an ice depth of $1.5 \mathrm{~km}, f$ value should be close to 0.7 . We decided to use this as a base and then calibrate the model (Farinotti et al., 2009) with a cross valley GPR transect at the gate (Rivera et al., 2010). Figure 2 shows the GPR transect. Figure 3 shows the values at the transect from different sources including ones modeled in this study. Using this approach we set $f$ as 0.78 , then with this value we calculated basal shear stress $\tau_{b}$ as (Hooke, 2005; Benn et al., 2010):

$$
\tau_{b}=f \rho g H \tan \alpha
$$

Where $\rho=917 \mathrm{~kg} \mathrm{~m}^{-3}, g=9.8 \mathrm{~m} \mathrm{~s}^{-1}$ and $\alpha$ the slope derived from TanDEM-X 
digital elevation model. In order to reduce the effect of longitudinal stresses (Kamb and Echelmeyer, 1986; Farinotti et al., 2009; Gantayat et al., 2014) the DEM was resampled to a coarser resolution using the median. The resulting DEM was smoothed with a 9x9 window filter. The median of the slope obtained between every 100 elevation contour was used for our purpose. Using equations 2 and 3 we find:

$$
H=\sqrt[4]{\frac{2\left(U_{s}-U_{b}\right)}{A C^{3}(\rho g \tan \alpha)^{3}}},
$$

Before applying equation 4 to Union glacier basin, the glacier outline is digitalized down to the grounding line using a high resolution TanDEM-X slope and the ice flow field generated from ice surface displacements complemented with MEaSUREs data (Rignot et al., 2017). Then, the surface velocities are estimated with a final pixel resolution of $100 \times 100$. Ice thickness is calculated for the glacier outline inside the Cosmo-SkyMED extent with a $100 \times 100$ pixel spacing, which is further smoothed using a $9 \times 9$ window median filter. Results are calibrated with a GPR transect at the gate figure 3a done by Rivera et al. (2010) and validated with 4107 GPR data points collected over the main valley, $f$ and $A$ parameters where adjusted in the calibration process. GPR data was gathered by Centro de Estudios Cientificos (CECS) during four different polar campaigns, with some of the data already published by Rivera et al. (2014b)

Figure 2: GPR and ice velocity ground data is presented, in green the glacier outline, yellow dots ice velocity ground data, in blue the GPR 4107 validation points and in red the GPR calibration data at the gate transect. GPR and ice velocity ground data collected during different campaigns between 2008 and 2010. Base image is Cosmo-SkyMED from 14 January 2012

The parameters used in equation 4 are the source of uncertainties in the ice thickness estimation (Farinotti et al., 2009), which can be expressed, by differentiating the equation 4 (Gantayat et al., 2014):

$$
\frac{d H}{H}=\frac{1}{4}\left[\frac{d U_{s}}{U_{s}}-\frac{d A}{A}-3 \frac{d f}{f}-3 \frac{d \rho}{\rho}-3 \frac{d \tan \alpha}{\tan \alpha}\right],
$$

The values are defined as follows; (i) we already resolved uncertainties in $U_{s}$ associated with errors in co-registration and tracking algorithm in section 3.2. Following Rivera et al. (2010) 
$U_{b}$ was set at zero; (ii) The flow factor or creep parameter $A$ over a glacier depends primarily on the variability of ice temperature, grain size, pressure, density, water content and impurities along the glacier. In order to express inherent uncertainties $(d A)$ we will use the difference between Rivera et al. (2010) chosen value for the investigated area and ours taken from literature (Cuffey and Paterson, 2010); (iii) There are three sources of uncertainties that $f$ accounts for (Farinotti et al., 2009): approximation of the shear stress (Nye, 1965), the distribution of basal drag across the profile (Van der Veen, 2013) and any rate of basal sliding would be concealed within this factor. At the gate transect that we use for calibration, the mean absolute error is $199.6 \mathrm{~m}$ giving an error of $14 \%$ for the gate, and we set $d f$ as 0.1 following Gantayat et al. (2014); (iv) We set a $10 \%$ difference on density $\rho$ to account for variations over the glacier profile such that $d \rho$ is set to $91.7 \mathrm{~kg} \mathrm{~m}^{-3} ;(\mathrm{v})$ Uncertainties associated with slope are directly related with TanDEM-X vertical accuracy $(2 \mathrm{~m})$, which gives a value of 0.043 for ${ }^{d \tan \alpha} /_{\tan \alpha}$. Putting all the values in equation 5 gives an error of $16.4 \%$ in ice thickness.

Figure 3: Profiles of the ice surface and bedrock of Union Glacier, where (a) transverse cross-section bedrock transect, that was used for calibration, and (b) longitudinal bedrock transect that goes into Driscoll valley, one of the tributaries. Both transects compare our model (grey) with: model created with MEaSUREs v2 velocities as input (green), BEDMAP2 bedrock (blue) and GPR measurements (orange), with the TanDEM-X WorldDEM (purple) as surface reference. Transect a) is in Rivera et al. (2010) and transect b) is in Rivera et al. (2014b). Axis are not ate the same scale

\subsection{Surface strain rates of Union Glacier}

Union glacier is considered a glacier with a frozen bed (Rivera et al., 2010), meaning that it advances only by creep due to deformation of ice. Strain is the deformation of a material owing to forces applied to it. When strain is measured over a certain amount of time it becomes a strain rate denoted by the letter $\dot{\varepsilon}$ (Hooke, 2005). Surface strain rates fields over a glacier can be derived from surface ice velocities (Nye, 1959; Harper et al., 1998). assuming that $\frac{\partial u_{i}}{\partial x_{j}}$ and $\frac{\partial u_{j}}{\partial y_{i}}$ do not change with depth, using equation 6 , we can obtain nine independent strains (Harper et al., 1998; 
Hooke, 2005; Van der Veen, 2013). We calculated strain rates over Union glacier in a $100 \times 100$ grid, differentiating the horizontal velocity grid (Harper et al., 1998), where:

$$
\dot{\varepsilon}_{i j}=\frac{1}{2}\left(\frac{\partial u_{i}}{\partial x_{j}}+\frac{\partial u_{j}}{\partial y_{i}}\right),
$$

Using only the four components that are parallel to the glacier surface we can calculate the horizontal strain rates associated with the surface velocities components $u$ and, where $u$ is the down-glacier ( $x$ axis) and $v$ cross-glacier ( $y$ axis), following the direction of the main flux. Then the magnitudes and direction of the least tensile $\dot{\varepsilon}_{1}$ and the most tensile $\dot{\varepsilon}_{3}$ over the horizontal $x y$ plane are obtained:

$$
\begin{aligned}
& \dot{\varepsilon}_{1}=\frac{1}{2}\left(\dot{\varepsilon}_{x}+\dot{\varepsilon}_{y}\right)-\sqrt{\left[\frac{1}{4}\left(\dot{\varepsilon}_{x}-\dot{\varepsilon}_{y}\right)^{2}+\dot{\varepsilon}_{x y}\right]} \\
& \dot{\varepsilon}_{3}=\frac{1}{2}\left(\dot{\varepsilon}_{x}+\dot{\varepsilon}_{y}\right)+\sqrt{\left[\frac{1}{4}\left(\dot{\varepsilon}_{x}-\dot{\varepsilon}_{y}\right)^{2}+\dot{\varepsilon}_{x y}\right]}
\end{aligned}
$$

and

$$
\Phi=\arctan \left(2 \frac{\dot{\varepsilon}_{x y}}{\dot{\varepsilon}_{x}-\dot{\varepsilon}_{y}}\right),-\frac{\pi}{4}<\Phi<\frac{\pi}{4}
$$

Where $\Phi$ relates to the angle associated with the direction between the $y$ axis and the principal stress axes (Nye, 1959; Harper et al., 1998). Possible errors in the strain rate field calculations are closely associated with the quality of the velocity field (Rankl et al., 2017). In order to reduce the errors, the analysis will be restricted to areas with ice movement greater than the mean flow velocity calculated over the main branch of the glacier $\left(\geq 0.0348 \mathrm{~m} \mathrm{~d}^{-1}\right)$.

The main objective of the strain rate calculations is relate them to surface glaciological features (eg. crevasses) that can be seen over high resolution SAR Cosmo-SkyMED Spotlight-2 images and associate their formation with flow dynamics. Crevasses in SAR images can be detected as bright lines due to high backscatter due to the geometry of the surface terrain. Moreover electromagnetic radiation at wavelengths used by SAR sensors is able to penetrate the dry-snowpack, showing buried crevasses (Colgan et al., 2016). We selected three areas (figure 1), covered by the Spotlight-2 SAR images, which present crevasses and have velocities above the mean ice surface velocity. Subsequently, we analyzed area (1) over a longitudinal crevasse field, area (2) which covers marginal crevasses and area (3) a compression zone where velocities are 
reduced drastically.

\section{Results}

\subsection{Ice Velocities}

Figure 4 the ice velocity field of Union glacier over the extent of the Cosmo-SkyMED SAR image and figure $4 \mathrm{~d}$ indicates the surface ice surface flow direction. Two pair of images were used, pair 1 (between 14 January of 2012 to 30 January of 2012, figure 4a) and pair 2 (between 21 December of 2011 to 22 January of 2012, figure 4), in order to generate two velocity maps with very similar results, as can be seen on figure $4 \mathrm{c}$ where the difference between them is shown. The results from the longer period (32 days, pair 2 on table 2) showed areas with some noise (i.e., velocity outliers can be seen on figure 4 b) over the main valley. There were attempts to improve this results choosing different window sizes over the offset tracking algorithm or changing the SNR values, but without success. The pair 2 (figure 4) results were polluted with either noise or areas with no data, this can be noted with the difference of the two images as seen on figure 4c. Thus, becoming counterproductive to be used either as input for ice thickness modeling or strain rate calculations. Therefore, results from pair 1 (figure 4a) where used for ice thickness estimation and strain rates. Maximum, mean velocities and standard deviation are obtained for the main trunk:these are $0.325 \mathrm{~m} \mathrm{~d}^{-1}, 0.043 \mathrm{~m} \mathrm{~d}^{-1}$ and $0.0393 \mathrm{~m} \mathrm{~d}^{-1}$ respectively.

We plot surface velocities over the center line of the glacier and compared them with changes in elevation, showing that higher velocities are associated with changes in elevation (figure 5). We can observe this over the area where the ice sheet flows from the plateau towards the valley, with a change in elevation of $500 \mathrm{~m}$ in an along section of about $13000 \mathrm{~m}$. Then, the ice slows its pace when Union glacier main trunk meets its tributary Schanz glacier. This area is coincident with the main blue ice sector of the glacier. The next relative acceleration of the flow is related with the shallow ice thickness (shown by a red arrow on figure 6) that creates a change over the glacier elevation as seen on the $30800 \mathrm{~m}$ mark over the central line transect.

Figure 4: Union glacier surface velocities magnitudes obtained by SAR offset tracking algorithm,

a) with 16 days and b) 32 days interval between acquisitions, color scale is truncated at $\left.0.15 \mathrm{~m} \mathrm{~d}^{-1} ; \mathrm{c}\right)$ the absolute difference between the pairs in $\mathrm{m} \mathrm{d}^{-1}$ and color scale is truncated at 
$0.07 \mathrm{~m} \mathrm{~d}^{-1}$; d) Main ice flow direction scaled by the magnitude of the velocity.

Figure 5: Union glacier center line velocity $\left(\mathrm{m} \mathrm{d}^{-1}\right)$ profile in orange and TanDEM-X altitude $(\mathrm{m}$ a.s.1.). Center line transect shown in blue over Landsat- 8 true color image (RGB 432).

\subsection{Ice Thickness}

Figure 6: Results of the model for estimating ice thickness using different surface ice velocities from a) Cosmo-SkyMED 16 days interval and b) MEaSUREs project data (Rignot et al., 2017).

The ice thickness model created for Union glacier and its tributaries is shown in figure 6 . The ice volume estimate for the glacier area covered by the extent of the SAR images is of $686.6 \mathrm{~km}^{3}$. The deepest point of the model is 2080 with a mean thickness of 952.61 for Union glacier main trunk. Figure 3 shows in (a) trans verse cross-section bedrock transect, that was used for calibration, and (b) longitudinal bedrock transect that goes into Driscoll valley, one of the tributaries. Both transects compare our model with: model created with MEaSUREs v2 velocities as input, BEDMAP2 bedrock and GPR measurements, with the TanDEM-X DEM as surface reference. Transect a) is in Rivera et al. (2010) and transect b) is in Rivera et al. (2014b).

Results were validated with 4107 GPR data points collected over the main valley. In order to assess the accuracy of the model of glacier ice thickness and to compare the same model with different ice velocity input (section 5.2), we calculated average ( $0.04957 \mathrm{~m})$, median (12.57 $\mathrm{m})$ and the interquartile range $( \pm 310.33 \mathrm{~m})$ of the difference between our model and the $4107 \mathrm{GPR}$ measurements, with a mean absolute deviation of $248.13 \mathrm{~m}(19.22 \%$ of the mean model thickness) and a residual standard error of $318.7 \mathrm{~m}$ of our model versus the GPR measurements.

Figure 7: Modeled bedrock of Union glacier using surface ice velocities from a) Cosmo-SkyMED 16 days interval and b) MEaSUREs project data (Rignot et al, 2017). The boundary of 0 meters a.s.l. is shown in green.

We subtracted the thickness model generated from a smoothed TanDEM-X DEM surface 
topography in order to obtain the bedrock topography (figure 7). A smoothed DEM was used in order to reduce any effects of surface glacier features and trespassed to the modeled bedrock (Farinotti et al., 2009).

\subsection{Crevassed areas and Strain rates}

We plotted the most and the least tensile principal strain rates in the horizontal $X Y$ plane over each area ( $\dot{\varepsilon}_{3}$ and $\dot{\varepsilon}_{1}$ ), figures ??. Therefore, our results show that in general, the first area (figure 8), is more tensile than compressive; the second area (figure 9) on the contrary, shows compression as a dominant characteristic; and the third area (figure 10) shows significant variations between compression and extension. The crevassed areas detected with SAR Cosmo-SkyMED Spotlight-2 images are in agreement with the crevasse fields detected by Rivera et al. (2014a).

Figure $8 \mathrm{~b}$ displays the axes of principal strain rate over the area number 1 on figure 2 . This area is approximately of dimensions $2 \times 2 \mathrm{~km}$ and shows a transverse crevasse formation and then closing, with ice surface velocities ranging between $13 \mathrm{ma}^{-1}$ and $39 \mathrm{ma}^{-1}$. Positive tensile stresses dominate the principal strain axes over this area. Principal strain axis in tension are at a small angles to the mean flux directions, going towards the west/left edge of the image. Most tensile horizontal axis are at right angle with crevasses at the bottom of the image, where the generation of the crevasse field is thought to be. Transverse crevasses at this area are formed due to an abrupt change of bedrock topography, a shallow pinning point that acts as a barrier for the upcoming ice flow, which results in compression (bottom of the Figure 8). Consequently, the crevasses are generated through extending flow due to speedup of ice mass (top of the Figure 8) (Hambrey and Lawson, 2000).

Figure 8:a) Enlarged area highlighting trans verse crevasses, ice velocity main flow direction over a Spotlight-2 image. b) Principal strain rates plotted over the same area, $\dot{\varepsilon}_{1}$ in blue and in $\dot{\varepsilon}_{3}$ red. Values are over a $1000 \mathrm{~m} \times 1000 \mathrm{~m}$ grid. Map extent is shown as 1 on figure 1

Figure $9 \mathrm{~b}$ displays the axes of principal strain rate for area number 2 , indicated in figure 2. This area extends over $1.6 \mathrm{~km} \times 1.6 \mathrm{~km}$ and was chosen because of the crevasses formed at the 
lateral margins and the strain rates associated. The area is on a major blue ice feature where where limited ablation occurs due to snow drift and sublimation (Bintanja, 1999; Rivera et al., 2010). In the region there is no surface melting apart from very occasional very hot summers such as the experienced in 1997 (Carrasco et al., 2000). This area consists of several marginal crevas ses where compressive flow dominates and a zone of longitudinal crevasses parallel to the main flow. The lateral stress can be observed on the magnitude of the compression of the principal axes with the most tensile principal axis normal to crevasse formation, where marginal crevasses are formed.

Figure 9: a) Enlarged area highlighting a zone with marginal and longitudinal crevasses parallel to the main flow direction over a Spotlight-2 image. b) Principal strain rates plotted over the same area, $\dot{\varepsilon}_{1}$ in blue and in $\dot{\varepsilon}_{3}$ red. Values are over a $1000 \mathrm{~m} \times 1000 \mathrm{~m} 1000$ grid. Map extent is shown as 2 on figure 1 . There is a large area with no velocity data.

Figure $10 \mathrm{~b}$ displays the axes of principal strain rate for the area number 3 indicated in Figure 2. This area is about $2 \mathrm{~km} \times 2 \mathrm{~km}$ and was chosen due to the compressive flow where the fastest part of the glacier enters the main valley that is buttressed by the ice shelf. We can observe evidence of the closure of the crevasse field as a consequence of the compressive flow. Moreover, the dominance of the least tensile principal axis could imply thrust-faulitng by compressive flow due to reduced ice velocity at this part of the glacier (Colgan et al, 2016). The pattern of principal strain rates shows that the most tensile dominates up-glacier, whereas the least tensile strain rates dominate down-glacier, accordingly with the patterns of opening and closing of the crevasse field. The bottom area that appears to be free of crevasses and shows patterns that probably represent an isotropic point, an area where the glacier surface would be structurally stable (Nye, 1983). The pattern showed by the contourlines drawn by the axes of the principal strain rates resemble an isotropic star, also there is a change from extension to compression, this could indicate a isotropic point (Nye, 1986; Harper et al., 1998).

Figure 10: a) Enlarged area highlighting compressive flow and possible thrust-faulting area and main flow direction over a Spotlight-2 image.b) Principal strain rates plotted over the same area, $\dot{\varepsilon}_{1}$ in blue and in $\dot{\varepsilon}_{3}$ red. Values are over a $1000 \mathrm{~m} \times 1000 \mathrm{~m}$ grid. Map extent is shown as 3 on figure 1 


\section{Discussion}

\subsection{Ice Velocities}

Glacier ice flow driven by creep is expected to have higher velocities associated with steep terrain or abrupt changes in elevation. In the case of Union glacier, this affirmation is correct for the two areas where the velocities are higher. In the first case, when the ice flux coming from the plateau descends into Union glacier valley and in the second case over the main valley, an area where a change in elevation exists due to a rise on the bedrock. This area has been acknowledged as a pinning point of the glacier (Rivera et al., 2014b). Beside this last mentioned area, velocities over the main trunk are slower and decrease as they get closer to the grounding line. This could be because changes in hypsometry, ice shelf buttressing, the faster flow of the Rutherford ice stream, that can exceed $1.2 \mathrm{~m} \mathrm{~d}^{-1}$ (Gudmundsson, 2006), could suppress Union glacier outlet flow or the widening and deepening of the valley topography, after exiting the constrains of the mountain valley. Finally our surface ice velocities results are in agreement with field measurements and previous studies (Rivera et al., 2010, 2014b), as shown on Table 3, with higher differences over slower areas of the glacier as shown in figure 11. The mean difference between Cosmo-SkyMED derived velocities and field measurements is $0.0202 \mathrm{~m} \mathrm{~d}^{-1}$ and for MEaSUREs ice velocity model is $0.0102 \mathrm{~m} \mathrm{~d}^{-1}$, both are within ice velocities errors.

Figure 11: Percentage of the differences of the velocities between Pair 1 (blue) and MEaSUREs V2 (green) (Rignot et al., 2017). Inset b) shows the gate area

Table 3: Comparison of field measures velocities with: Cosmo-SkyMED (CSK) derived surface velocities and MEaSUREs velocities. Data is in $\mathrm{m} a^{-1}$ and the percentage difference at each point was calculated. GPS stations are shown in Figure 2 and with more detail in Figure 2 and Table 2 of Rivera et al. (2014b). B14 to V21 are located at the gate transect, while other stakes (B08 to B13) are distributed along the glacier and further down flow.

\begin{tabular}{|c|c|c|c|c|c|c|}
\hline \multirow{3}{*}{$\begin{array}{l}\text { GPS } \\
\text { Station }\end{array}$} & Longitude & Latitude & Vel. at & Vel. CSK & Diff. CSK & Diff \\
\hline & & & Station & & MEaSUREs (\%) & MEaSUREs \\
\hline & & & & & & (\%) \\
\hline
\end{tabular}




\begin{tabular}{|c|c|c|c|c|c|}
\hline$\overline{\mathrm{B} 08}$ & $-81.965195-79.7568512 .9$ & 8.14212 & 4.733 & 180.763 & 63.207 \\
\hline B09 & $-82.453419-79.70853633 .3$ & 26.54531 & 33.04971 & 20.284 & 0.752 \\
\hline B10 & -82.641123 -79.717176 34.6 & 25.73869 & 29.16082 & 25.611 & 15.72 \\
\hline B11 & $-82.801592-79.75672920 .5$ & 12.18427 & 19.91661 & 40.565 & 2.846 \\
\hline B12 & -82.930014 -79.759971 20.9 & 21.90316 & 17.34298 & 4.8 & 17.019 \\
\hline B13 & 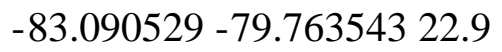 & 16.49623 & 17.18211 & 27.964 & 24.969 \\
\hline B14 & $-83.264633-79.76749122 .4$ & 17.90486 & 18.92085 & 20.068 & 15.532 \\
\hline B15 & $-83.280006-79.79834421 .6$ & 19.38556 & 18.66613 & 10.252 & 13.583 \\
\hline B16 & $-83.314627-79.79556423 .2$ & 20.4633 & 21.58851 & 11.796 & 6.946 \\
\hline B17 & $\begin{array}{ll}-83.34264 & -79.76517517\end{array}$ & 12.01598 & 14.74416 & 29.318 & 13.27 \\
\hline B18 & $\begin{array}{lll}-83.36934 & -79.75951 & 14\end{array}$ & 5.38646 & 8.46782 & 61.525 & 39.516 \\
\hline B19 & $-83.371064-79.76444111 .1$ & 10.13483 & 12.77598 & 8.695 & 15.099 \\
\hline V00 & $-83.369388-79.76879118 .1$ & 12.83947 & 15.31552 & 29.064 & 15.384 \\
\hline V01 & $-83.369341-79.76994619$ & 14.06536 & 15.31552 & 25.972 & 19.392 \\
\hline V02 & $-83.367162-79.77150520 .2$ & 6.29582 & 18.01662 & 19.328 & 10.809 \\
\hline V03 & -83.364462 -79.77344321 .7 & 19.33093 & 18.01662 & 10.917 & 16.974 \\
\hline V04 & $-83.361998-79.77521922 .3$ & 20.83477 & 20.07374 & 6.571 & 9.983 \\
\hline V05 & $-83.359514-79.77702223$ & 20.18964 & 20.07374 & 12.219 & 12.723 \\
\hline V06 & $-83.356688-79.77908623 .5$ & 21.60385 & 21.63159 & 8.069 & 7.951 \\
\hline V07 & $-83.354061-79.78102623 .9$ & 21.23055 & 21.63159 & 11.169 & 9.491 \\
\hline V08 & $-83.350741-79.78349624 .3$ & 22.28339 & 20.91835 & 8.299 & 13.916 \\
\hline V09 & $-83.341676-79.78641424 .3$ & 22.91436 & 20.99335 & 5.702 & 13.608 \\
\hline V10 & $-83.332414-79.78941624 .3$ & 22.71367 & 23.42099 & 6.528 & 3.617 \\
\hline V11 & $-83.323661-79.79226424$ & 22.48447 & 23.48683 & 6.315 & 2.138 \\
\hline V12 & $-83.336449-79.77139921 .9$ & 18.18857 & 20.9301 & 16.947 & 4.429 \\
\hline V13 & $\begin{array}{lll}-83.333563-79.77281 & 22.3\end{array}$ & 18.38385 & 20.9301 & 17.561 & 6.143 \\
\hline V14 & -83.330481 -79.774309 22.4 & 18.06 & 23.76561 & 19.375 & 6.096 \\
\hline V15 & $-83.325526-79.77673222 .7$ & 17.84213 & 23.76561 & 21.4 & 4.694 \\
\hline V16 & $-83.321717-79.77859723 .1$ & 19.42115 & 25.90773 & 15.926 & 12.155 \\
\hline V17 & $-83.315057-79.78188123 .4$ & 20.61393 & 25.27186 & 11.906 & 7.999 \\
\hline V18 & -83.311571-79.783605 23.5 & 19.93941 & 25.27186 & 15.151 & 7.54 \\
\hline
\end{tabular}




\begin{tabular}{lllllll} 
V19 & $-83.307388-79.78567923 .6$ & 20.28917 & 25.46391 & 14.029 & 7.898 \\
V20 & $-83.302111-79.78830123 .3$ & 20.70112 & 25.46391 & 11.154 & 9.287 \\
V21 & $-83.296554-79.79108123$ & 20.73947 & 24.31866 & 9.828 & 5.733 \\
\hline
\end{tabular}

\subsection{Ice Thickness}

The thickness of a cold base glacier influences directly its dynamics, creep by deformation is how it advances, and this depends on the topographic constrains where the glacier is based (eg. rock margins, slope, bedrock promontories). For example, the higher the slope, the thinner the glacier (Nye, 1952a).

In our case, due to the chosen value for the constant $n$ in Glen's flow law (Glen, 1955), slope and factor $f$, have three times more effect over the ice thickness model, than a change in surface or basal ice velocity. In this regard a smooth slope that represents in the best way possible the angle relative to the plane where the glacier is resting and not surface slope variations, this can be described as a parallel-sided slab model (Cuffey and Paterson, 2010).

Previous GPR measurements over Union Glacier showed a shallow area that is indicated as a pinning point for the glacier (Rivera et al. (2014b), figures 6 and 8). This same area can be observed on the model (red arrow on figure 6 ) and it shows that spans over the entire width of the glacier. This means that in case of a retreat in the position of the grounding line (Ross et al., 2012), the glacier will retreat at a first stage towards this point. But after that shallower area the glacier deepens until the bedrock starts gaining elevation at the confluence of the tributaries.

The results of our model showed that the whole main glacier trunk is under sea level, under present isostatic equilibrium. This makes Union glacier sensible to a possible future Ronne-Filchner disintegration (Hellmer et al., 2012, 2017). However, if we take into consideration glacial isostatic adjustment (Watts, 2001) shallow areas (eg. pinning point) could end above sea level.

We also generated an ice thickness model using ice velocities from the MEaSUREs project (Rignot et al., 2011a). The main objective behind this was to test a high resolution velocity product with a freely available ice velocity model for the whole Antarctica. Ice thickness and sub-glacier bedrock can be seen in figures 6 and 7 respectively. In order to estimate the difference between them, we used the same parameters and validated against the 4107 GPR points. That gave us an average $(-251.9 \mathrm{~m})$, median $(-316.9 \mathrm{~m})$ and the interquartile range $( \pm 421.4 \mathrm{~m})$, then we 
calculated the mean absolute deviation of $317.0 \mathrm{~m}(21.43 \%$ of the mean model thickness $)$ and a residual standard error of $219.4 \mathrm{~m}$. Also a graphical comparison can be seen in figure 3 . This comparison suggests that for a mountainous area like the Heritage range, MEaSUREs has a good representation of surface ice velocities and can be used as an input for modelled ice thickness.

Both ice thickness estimations have similar mean absolute deviations $(21.28 \%$ Cosmo-SkyMED and 21.43\% MEaSUREs) with respect to the GPR measurements used for model validation, $16.6 \%$ of that difference could be explained by the uncertainties of the model. The remaining difference on ice thickness estimation, could be explained if we add the GPR uncertainties on accuracy. There area between 5\% to 10\% (Fischer, 2009). The error on the model reflects the inadequacy of the model to represent small changes over the bedrock because of the assumption of a parallel-sided slab model. This simplification that assumes that the surface slope is parallel to the bedrock slope induced to a poor representation of the bedrock slope between the pinning point and the valley as we can see on Figure $3 b$.

Figure 12: Ice thickness of Union Glacier outline using MEaSUREs surface ice velocity as input.

As the Cosmo-SkyMED HIMAGE scene does not cover the whole glacier outline, from the plateau to the grounding line, and we prove that the MEaSUREs data set reflects quite well the surface ice velocity of the glacier, except in areas with lower velocities. We use the MEaSUREs data to model the whole glacier outline ice thickness (figure 12). Complete estimates of glacier ice volume and sea level equivalent where obtained. The total ice volume of the defined glacier outline is $1651.543 \mathrm{~km}^{3}$ with a total mass of $1513.969 \mathrm{Gt}$, considering an ice density of $0.9167 \mathrm{Gt} / \mathrm{km}^{3}$. Sea level equivalent was calculated taking in consideration that space occupied by the ice below sea level would not contribute to sea level rise, because seawater will occupy that space (Haeberli and Linsbauer, 2013). The volume of ice above sea level is $706.32 \mathrm{~km}^{3}$ with a mass of $647.48 \mathrm{Gt}$. That will gave us that Union glacier has an ice a sea level equivalent of $1.79 \pm 0.46 \mathrm{~mm}$.

\subsubsection{Ice thickness sensitivity analysis}

We made a sensitivity analysis over $U_{b}$ and $f$ parameters of equation 2 , in order to 
observe variations in ice thickness estimates. We did this for two different cross-profiles A-A' and B-B' ( figure 13). We vary $U_{b}$ within $10 \%, 20 \%$ and $30 \%$ of $U_{s}$ and found that a variation of $10 \%$ does not change the results substantially, changing about 50 meters with every $10 \%$ shift in $U_{b}$, which is $5 \%$ to $3 \%$ of the total ice thickness for that section. In this respect, the existence of relative low basal velocities $U_{b}$ would affect in a very small percent to the overall ice thickness and calculated volume.

However, different values of $f(0.99,0.9,0.8,0.7)$ yield a variation of more than $10 \%$ over in mean ice thickness for each section. This is similar to Farinotti et al. (2009), they found that a change of 0.1 over $f$ (called correction factor $C$ in their study) yielded a variation in $9 \%$ over the mean ice thickness. If using $f$ as a calibration parameter, there should exist at least some ground data measurements in order to adjust the value, this improve results significantly. While having in consideration the geometry of the basin.

Previous studies had shown that laminar flow model is sensitive to the $f$ factor and $A$ parameter chosen (Farinotti et al., 2009) and not as sensitive to changes in basal velocities (Gantayat et al., 2014).

Figure 13: Sensibility analysis of the variations of $U_{b}$ (a and b) and of $f$ (c and d), over two cross sections of the glacier B-B' (plot a and c) and C-C' (plot b and d). Map shows position of both transects.

\subsection{Strain Rates}

We relate surface principal strain rates with crevasse formation and found a good match between most tensile prevalence of strain rates and trans verse crevasses (figure 8), a change from most tensile predomination to least tensile predomination with closing of crevasses probably due to changes in ice velocity (figure 10), the formation of longitudinal crevasses and marginal crevasses over a blue ice area (figure 9).

Observing the areas studied (figures 8,9 and 10) one would be inclined to think of a low-advection life cycle (Harper et al., 1998; Colgan et al., 2016) of the Union glacier crevasse fields analyzed. We can observe clear evidence of low-advection life-cycle over the crevasse field in Figure 8, crevasses are generated at the bottom of the image with the most tensile principal axis 
perpendicular to the crevasse field direction. We could not find evidence of formation of crevasses up glacier progressing down glacier, this could be due to the topographic and glaciological constrains of Union glacier.

\section{Conclusion}

Using SAR offset tracking and high resolution SAR images we calculated surface ice velocities of an important area of Union glacier. We applied this results in combination with TanDEM-X to model ice thickness over the glacier and is tributaries, applying a lamellar flow model and the relation between driving stresses and basal drag. Finally we used the surface ice velocities to compute principal strain rates and relate them with glacier surface features.

Derived SAR surface ice velocities yield a maximum of $0.326 \mathrm{~m} \mathrm{~d}^{-1}$, a mean $0.0432 \mathrm{~m} \mathrm{~d}^{-1}$ with a SD of $0.0393 \mathrm{~m} \mathrm{~d}^{-1}$ for Union glacier, this values are in agreement with previous studies and sustains the theory of a frozen bed (Rivera et al., 2010, 2014b). Areas with higher velocities are associated with strong changes in elevation, however Union glac ier is heavily buttressed by the Ronne ice shelf and the Ruthford ice stream flux preventing higher velocities to occur.

The combination of different remote sensing datasets (SAR satellite imagery and GPR measurements), allow us to generate a model estimation of ice thickness for the glacier. The calibration of the model with in-situ GPR measurements proof to gave us a better estimate of ice thickness. The use of MEaSUREs ice velocity dataset gave not much difference than using high-resolution SAR offset tracking on the overall ice thickness model, except on areas with low velocities. As stated by Farinotti et al. (2017), the use of public datasets of surface ice velocity data should be taken into advantage for future ice thickness estimations over Antarctica. Using the MEaSUREs data set a complete ice thickness model of Union Glacier was generated, from which the total volume, mass and sea level equivalent was calculated, yielded a total of $1651.54 \mathrm{~km}^{3}$, 1513.969 Gt and $1.79 \mathrm{~mm}$ respectively. The possible future effect of Union glacier, over sea level rise was quantified and an opportunity to asses the volume of the whole Heritage range opened.

Parameters as $f$ factor and $A$, combined with field measurements can be used as a calibration parameter (Farinotti et al., 2009), this will reduce significantly the model estimation 
error if the $f$ value is not assumed correctly. Our results showed that changes over the $f$ value, a relation between driving stress and basal drag, are more important than variations on basal velocity $\left(U_{b}\right)$.

The ice thickness modeling approach used here does not contemplate the effects of longitudinal stresses and lateral drag over the glacier flow at a full scale, as a complete force balance equation would. Other limitations are the need of ice velocities estimates, that in some glaciers could be hard to obtain or validate, in-situ GPR data for calibration of the model and a measure of the slope of the glacier that is a close match to the bedrock slope, herein unaffected by surface features. However, our results showed that a model based on lamellar flow is a good estimate for ice thickness, which could be used in other mountain areas in Antarctica.

High resolution SAR images that are in the order of $1 \mathrm{~m}$ resolution used in association with derived products from medium resolution SAR images can be used in order to establish relations between surface features and complex ice dynamics. Over Union glacier we showed the influence of bedrock topography on crevasse formation. Likewise we find evidence of what we relate to low-advection crevasse lifecycle.

\section{Acknowledgement(s)}

Cosmo-SkyMed images and TanDEM-X data used here were provided respectively by ASI and DLR through the following projects: COSMO-SkyMed data in support of climate sensitivity studies of selected glaciers in Antarctica, South America, the Arctic and Northern Europe (GlacioCOSMO), and TanDEM-X data in support of glacier mass balance and remote sensing studies of glaciers in Southern Patagonia and Ellsworth Mountains (Antarctica). The authors also acknowledge the logistical support by the Chilean Estaci $\tilde{A}^{3} n$ Polar Cient $\tilde{A}$-fica Conjunta Glaciar Unin and the private company ALE (Antarctic Logistic Expeditions).

Programa de pos graduacion en oceanografia quimica, fisica y gelogica. Universidade Federal do Rio Grande (FURG)

\section{Funding}

This study has been funded by the Council for Research and Scientific Development of Brazil (CNPq) through grants from the Brazilian National Institute of Science and Technology of 
Cryosphere (INCT-CRIOSFERA; CNPq grant no. 573720/2008-8) and the CNPq grant no. 461414/2014-7. The authors would like to thank Brazilian financial agencies J. Arigony-Neto acknowledges CNPq research grant n 305897/2013-6 and Rodrigo Gomez acknowledges CAPES scholarship XXXX. Saurabh Vijay acknowledges the funding from VILLUM FONDEN. Andrs Rivera was supported by CECS and the basal fund.

\section{References}

Bamber, J. L., Riva, R. E. M., Vermeersen, B. L. A., LeBrocq, A. M., 2009. Reassessment of the Potential Sea-Level Rise from a Collapse of the West Antarctic Ice Sheet. Science 324 (5929), 901-903.

URL

http://www.sciencemag.org/cgi/content/abstract/324/5929/90 1\% / 5 cnhttp: / / www.n

Benn, D. I., Evans, D. J. A., Nelson, S. A., 2010. Glaciers and Glaciation, 2nd Edition. Hodder Arnold Publication. Routledge.

URL

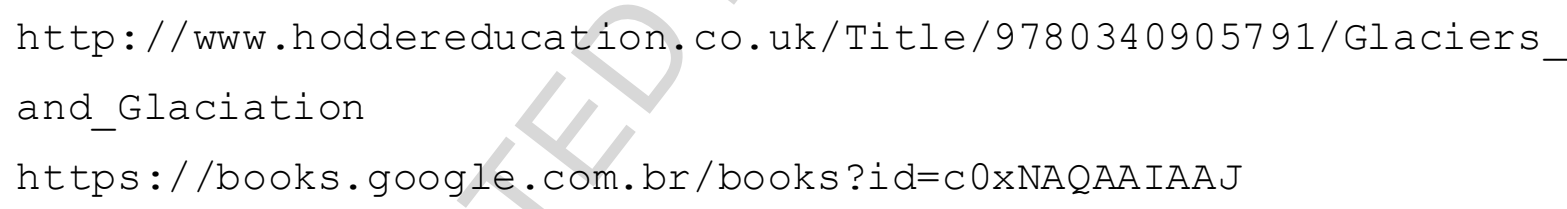

Bintanja, R., 1999. On the glaciological, meteorological, and climatological significance of Antarctic blue ice areas. Reviews of Geophysics 37 (3), 337-359.

URL http://doi.wiley.com/10.1029/1999RG900007

Carrasco, J. F., Cassasa, G., Rivera, A., 2000. A warm event at Patriot Hills, Antarctica: an ENSO related phenomenon. In: Sixth International Conference on Southern Hemisphere Meteorology and Oceanography. American Meteorological Society, Boston, MA, Santiago, Chile, pp. 240-241.

Cazenave, A., Lombard, A., Llovel, W., 2008. Present-day sea level rise: A synthesis. Comptes Rendus - Geoscience 340 (11), 761-770.

Ciappa, A., Pietranera, L., Battazza, F., 2010. Perito Moreno Glacier (Argentina) flow estimation by COSMO SkyMed sequence of high-resolution SAR-X imagery. Remote Sensing of Environment 114 (9), 2088-2096. 
Colgan, W., Rajaram, H., Abdalati, W., McCutchan, C., Mottram, R., Moussavi, M. S., Grigsby, S., 2016. Glacier crevasses: Observations, models, and mass balance implications. Reviews of Geophysics 54 (1), 119-161.

Cuffey, K., Paterson, W., 2010. The Physics of Glaciers, 4th Edition. Academic Press.

Depoorter, M. A., Bamber, J. L., Griggs, J. A., Lenaerts, J. T. M., Ligtenberg, S. R. M., van den

Broeke, M. R., Moholdt, G., 2013. Calving fluxes and basal melt rates of Antarctic ice shelves. Nature 502 (7469), 89-92.

URL http: / / www.ncbi.nlm.nih.gov/pubmed/24037377

Dutton, A., Carlson, A. E., Long, A. J., Milne, G. A., Clark, P. U., DeConto, R., Horton, B. P., Rahmstorf, S., Raymo, M. E., 2015. Sea-level rise due to polar ice-sheet mass loss during past warm periods. Science 349 (6244), aaa4019-aaa4019.

URL

http://www.sciencemag.org/cgi/doi/10.1126/science.aaa 4019\%5Cnh ttp: //www.sci

Falk, U., Gieseke, H., Kotzur, F., Braun, M., 2016. Monitoring snow and ice surfaces on King George Island, Antarctic Peninsula, with high-resolution TerraSAR-X time series. Antarctic Science 28 (02), 135-149.

URL

http: //www.journals.cambridge.org/abstract_s0954102015000577

Farinotti, D., Brinkerhoff, D. J., Clarke, G. K., Fürst, J. J., Frey, H., Gantayat, P., Gillet-Chaulet, F., Girard, C., Huss, M., Leclercq, P. W., Linsbauer, A., Machguth, H., Martin, C., Maussion, F., Morlighem, M., Mosbeux, C., Pandit, A., Portmann, A., Rabatel, A., Ramsankaran, R., Reerink, T. J., Sanchez, O., Stentoft, P. A., Singh Kumari, S., Van Pelt, W. J., Anderson, B., Benham, T., Binder, D., Dowdeswell, J. A., Fischer, A., Helfricht, K., Kutuzov, S., Lavrentiev, I., McNabb, R., Hilmar Gudmundsson, G., Li, H., Andreassen, L. M., 2017. How accurate are estimates of glacier ice thickness? Results from ITMIX, the Ice Thickness Models Intercomparison eXperiment. Cryosphere 11 (2), 949-970.

Farinotti, D., Corr, H., Gudmundsson, G. H., 2013. The ice thickness distribution of Flask Glacier, Antarctic Peninsula, determined by combining radioecho sound ings, surface velocity data and flow modelling. Annals of Glaciology 54 (63), 18-24.

Farinotti, D., Huss, M., Bauder, A., Funk, M., Truffer, M., 2009. A method to estimate ice volume 
and ice thickness distribution of alpine glaciers. Journal of Glaciology 55 (191), $422-430$.

Fischer, A., 2009. Calculation of glacier volume from sparse ice-thickness data, applied to Schaufelferner, Austria. Journal of Glaciology 55 (191), 453-460.

Fitzpatrick, A. A. W., Hubbard, A., Joughin, I., Quincey, D. J., Van As, D., Mikkelsen, A. P. B., Doyle, S. H., Hasholt, B., Jones, G. A., 2013. Ice flow dynamics and surface meltwater flux at a land-terminating sector of the Greenland ice sheet. Journal of Glaciology 59 (216), 687-696.

Fretwell, P., Pritchard, H. D., Vaughan, D. G., Bamber, J. L., Barrand, N. E., Bell, R., Bianchi, C., Bingham, R. G., Blankenship, D. D., Casassa, G., Catania, G., Callens, D., Conway, H., Cook, A. J., Corr, H. F., Damaske, D., Damm, V., Fer- raccioli, F., Forsberg, R., Fujita, S., Gim, Y., Gogineni, P., Griggs, J. A., Hind- marsh, R. C., Holmlund, P., Holt, J. W., Jacobel, R. W., Jenkins, A., Jokat, W., Jordan, T., King, E. C., Kohler, J., Krabill, W., Riger-Kusk, M., Langley, K. A., Leitchenkov, G., Leuschen, C., Luyendyk, B. P., Matsuoka, K., Mouginot, J., Nitsche, F. O., Nogi, Y., Nost, O. A., Popov, S. V., Rignot, E., Rippin, D. M., Rivera, A., Roberts, J., Ross, N., Siegert, M. J., Smith, A. M., Steinhage, D., Studinger, M., Sun, B., Tinto, B. K., Welch, B. C., Wilson, D., Young, D. A., Xiangbin, C., Zirizzotti, A., 2013. Bedmap2: Improved ice bed, surface and thickness datasets for Antarctica. Cryosphere 7 (1), 375-393.

Gantayat, P., Kulkarni, A. V., Srinivasan, J., 2014. Estimation of ice thickness using surface velocities and slope: Case study at Gangotri Glacier, India. Journal of Glaciology 60 (220), $277-282$.

Glen, J. W., 1955. The Creep of Polycrystalline Ice. Proceedings of the Royal Society of London. Mathematical, Physical Sciences and Engineering Sciences 228 (1175), 519-538.

Gudmundsson, G. H., 2006. Fortnightly variations in the flow velocity of Rutford Ice Stream, West Antarctica. Nature 444 (7122), 1063-1064.

Haeberli, W., Linsbauer, A., 2013. Brief communication Global glacier volumes and sea level \&ndash; Small but systematic effects of ice below the surface of the ocean and of new local lakes on land. Cryosphere 7 (3), 817-821.

Hambrey, M., Lawson, W., 2000. Glacier Flow and Structures. Geological Society, London, Special Publications (176), 59-83.

Harper, J. T., Humphrey, N. F., Pfeffer, W. . T., 1998. Crevasse patterns and the strain rate tensor: a high-resolution comparison. Journal of Glaciology 44 (146), 68-76.

Hellmer, H. H., Kauker, F., Timmermann, R., Determann, J., Rae, J., 2012. Twenty-first-century 
warming of a large Antarctic ice-shelf cavity by a redirected coastal current. Nature 485 (7397), 225-228.

URL http://www. nature.com/doifinder/10.1038/nature11064

Hellmer, H. H., Kauker, F., Timmermann, R., Hattermann, T., 2017. The fate of the Southern Weddell sea continental shelf in a warming climate. Journal of Climate 30 (12), 4337-4350. Hooke, R., 2005. Principles of Glacier Mechanics. Cambridge University Press.

Joughin, I., 2002. Ice-sheet velocity mapping: A combined interferometric and speckle-tracking approach. Annals of Glaciology 34, 195-201.

Kamb, B., Echelmeyer, K. A., 1986. Stress-Gradient Coupling in Glacier Flow: I. Longitudinal Averaging of the Influence of Ice Thickness and Surface Slope. Journal of Glaciology 32 (111), 267-284.

URL

https://www. cambridge.org/core/product/identifier/s 00221430000 15604 /type/jo

Krieger, G., Moreira, A., Fiedler, H., Hajnsek, I., Werner, M., Younis, M., Zink, M., 2007. TanDEM-X: A satellite formation for high-resolution SAR interferometry. IEEE Transactions on Geoscience and Remote Sensing 45 (11), 3317-3340.

LeDoux, C. M., Hulbe, C. L., Forbes, M. P., Scambos, T. A., Alley, K., 2017. Structural provinces of the Ross Ice Shelf, Antarctica.

McNabb, R. W., Hock, R., O’Neel, S., Rasmussen, L. A., Ahn, Y., Braun, M., Conway, H., Herreid, S., Joughin, I., Pfeffer, W. T., Smith, B. E., Truffer, M., 2012. Using surface velocities to calculate ice thickness and bed topography: A case study at Columbia Glacier, Alaska, USA. Journal of Glaciology 58 (212), 1151-1164.

Morlighem, M., Rignot, E., Seroussi, H., Larour, E., Ben Dhia, H., Aubry, D., 2011. A mass conservation approach for mapping glacier ice thickness. Geophysical Research Letters 38 (19), $1-6$.

Muto, M., Furuya, M., 2013. Surface velocities and ice-front positions of eight major glaciers in the Southern Patagonian Ice Field, South America, from 2002 to 2011. Remote Sensing of Environment 139, 50-59.

Nicholls, K. W., Østerhus, S., Makinson, K., Gammelsrød, T., Fahrbach, E., 2009. Ice-ocean processes over the continental shelf of the Southern Weddell Sea, Antarctica: A review. 
Reviews of Geophysics 47 (3).

Nye, J., 1952a. A Methods of Calculating the Thickness of the Ice-Sheets. Nature 169 (4300), 529-530.

Nye, J., 1952b. The mechanics of glacier flow. Journal of Glaciology 2 (January), 82-93.

Nye, J., 1959. A method of determining the strain rate tensor at the surface of a glacier (6), 1-11.

URL

papers2: / / publication/uuid/B878F358-4570-46EB-B40A-20FF5029B09 F

Nye, J., 1983. Monstars on glaciers. Journal of Glaciology 29 (101), 70-77.

Nye, J. F., 1965. The flow of a glacier in a channel of rectangular, elliptic or parabolic cross-section. J. Glaciol. 5, 661-690.

Nye, J. F., 1986. Isotropic points on glaciers. Journal of Glaciology 32 (January 1986), 363-365.

Osmanoglu, B., Navarro, F. J., Hock, R., Braun, M., Corcuera, M. I., 2014. Surface velocity and mass balance of Livingston Island ice cap, Antarctica. Cryosphere 8 (5), 1807-1823.

Pauling, A. G., Bitz, C. M., Smith, I. J., Langhorne, P. J., 2016. The response of the Southern Ocean and Antarctic sea ice to freshwater from ice shelves in an earth system model. Journal of Climate 29 (5), 1655-1672.

Poinar, K., Joughin, I., Das, S. B., Behn, M. D., Lenaerts, J. T. M., Van Den Broeke, M. R., 2015. Limits to future expansion of surface-melt-enhanced ice flow into the interior of western Greenland. Geophysical Research Letters 42 (6), 1800-1807.

Purkey, S. G., Johnson, G. C., 2013. Antarctic bottom water warming and freshening: Contributions to sea level rise, ocean freshwater budgets, and global heat gain. Journal of Climate 26 (16), 6105-6122.

Rankl, M., Jakob Fiirst, J., Humbert, A., Holger Braun, M., 2017. Dynamic changes on the Wilkins Ice Shelf during the 2006-2009 retreat derived from satellite observations. Cryosphere $11(3), 1199-1211$.

Rignot, E., Casas sa, G., Gogineni, P., Krabill, W., Rivera, A., Thomas, R., 2004. Accelerated ice discharge from the Antarctic Peninsula following the collapse of Larsen B ice shelf. Geophysical Research Letters 31 (18).

Rignot, E., Jacobs, S., Mouginot, J., Scheuchl, B., 2013. Ice-shelf melting around Antarctica. Science 341 (6143), 266-70. 
URL http://www.ncbi.nlm.nih.gov/pubmed/23765278

Rignot, E., Jacobs, S. S., 2002. Rapid bottom melting widespread near Antarctic Ice Sheet grounding lines. Science 296 (5575), 2020-2023.

Rignot, E., Mouginot, J., Scheuchl, B., 2011a. Antarctic grounding line mapping from differential satellite radar interferometry. Geophysical Research Letters 38 (10), n/a-n/a.

Rignot, E., Mouginot, J., Scheuchl, B., 2017. MEaSUREs InS AR-based Antarctica ice velocity map.

Rignot, E., Velicogna, I., Van Den Broeke, M. R., Monaghan, A., Lenaerts, J., $2011 \mathrm{~b}$. Acceleration of the contribution of the Greenland and Antarctic ice sheets to sea level rise. Geophysical Research Letters 38 (5), n/a-n/a.

Rivera, A., Cawk well, F., Wendt, A., Zamora, R., 2014a. Mapping blue-ice areas and crevasses in West Antarctica using ASTER images, GPS, and radar measurements. Global Land Ice Measurements from Space, 743-757.

URL http: //link.springer.com/10.1007/978-3-540-79818-7

Rivera, A., Zamora, R., Rada, C., Walton, J., Proctor, S., 2010. Glaciological investigations on Union Glacier, Ellsworth Mountains, West Antarctica. Annals of Glaciology 51 (55), 91-96.

Rivera, A., Zamora, R., Uribe, J. A., Jaña, R., Oberreuter, J., 2014b. Recent ice dynamic and surface mass balance of Union Glacier in the West Antarctic Ice Sheet. The Cryosphere 8 (4), $1445-1456$.

URL http: / / www . the-cryosphere.net/8z1445/2014/

Riveros, N., Euillades, L., Euillades, P., Moreiras, S., Balbarani, S., 2013. Offset tracking procedure applied to high resolution SAR data on Viedma Glacier, Patagonian Andes, Argentina. Advances in Geosciences 35, 7-13.

Ross, N., Bingham, R., Corr, H. F. J., Ferraccioli, F., Jordan, T., Le Brocq, A., Rippin, D., Young, D., Blankenship, D., Siegert, M. J., 2012. Steep reverse bed slope at the grounding line of the Weddell Sea sector in West Antarctica. Nature Geoscience 5 (6), 1-4.

URL http://dx.doi.org/DOI: 10.1038/NGEO1468

Sánchez-Gámez, P., Navarro, F. J., 2017. Glacier surface velocity retrieval using D-InSAR and offset tracking techniques applied to ascending and descending passes of sentinel-1 data for southern ellesmere ice caps, Canadian Arctic. Remote Sensing 9 (5), 1-17.

Satyabala, S. P., 2016. Spatiotemporal variations in surface velocity of the Gangotri glacier, 
Garhwal Himalaya, India: Study using synthetic aperture radar data. Remote Sensing of Environment 181, 151-161.

URL http: / /dx.doi.org/10.1016/j.rse.2016.03.042

Scambos, T. A., Bohlander, J. A., Shuman, C. A., Skvarca, P., 2004. Glacier acceleration and thinning after ice shelf collapse in the Larsen B embayment, Antarctica. Geophysical Research Letters 31 (18).

Schmidtko, S., Heywood, K. J., Thompson, A. F., Aoki, S., 2014. Multidecadal warming of Antarctic waters. Science 346 (6214), 1227-1231.

Strozzi, T., Luckman, A., Murray, T., Wegmuller, U., Werner, C. L., 2002. Glacier motion estimation using SAR offset-tracking procedures. IEEE Transactions on Geoscience and Remote Sensing 40 (11), 2384-2391.

URL http: / / eprints.whiterose.ac.uk/747/

Turner, J., Barrand, N. E., Bracegirdle, T. J., Convey, P., Hodgson, D. A., Jarvis, M., Jenkins, A., Marshall, G., Meredith, M. P., Roscoe, H., Shanklin, J., French, J., Goosse, H., Guglielmin, M., Gutt, J., Jacobs, S., Kennicutt, M. C., Masson-Delmotte, V., Mayewski, P., Navarro, F.,

Robinson, S., Scambos, T., Sparrow, M., Summerhayes, C., Speer, K., Klepikov, A., 2014. Antarctic climate change and the environment: an update. Polar Record 50 (03), 237-259. URL

http://journals.cambridge.org/action/displayAbstract?aid=92855 25

Van der Veen, C., 2013. Fundamental of Glacier Dynamics. CRC Press.

Vijay, S., Braun, M., 2017. Seasonal and interannual variability of Columbia Glacier, Alaska (2011-2016): Ice Velocity, Mass Flux, surface elevation and front position. Remote Sensing 9 (6), 1-18.

Watts, A., 2001. Isostasy and Flexure of the Lithosphere. Cambridge University Press, Cambridge, UK.

Wegmuller, U., Werner, C., Strozzi, T., 1998. SAR interferometric and differential interferometric processing $\backslash$ nchain. IGARSS '98. Sensing and Managing the Environment. 1998 IEEE International Geoscience and Remote Sensing. Symposium Proceedings. (Cat. No.98CH36174) 2 (AUGUST 1998), 1-4.

Werner, C., Wegmuller, U., Strozzi, T., Wiesmann, A., 2000. GAMMA SAR and interferometric 
processing software. European Space Agency, (Special Publication) ESA SP (461), 211-219. Young, N. W., Hyland, G., 2002. Velocity and strain rates derived from InSAR analysis over the Amery Ice Shelf, East Antarctica. Annals of Glaciology 34, 228-234. 


\section{Highlights}

- SAR images derived products like ice velocities combined with SAR data are used to derived ice dynamics of an outlet glacier in the Ellsworth mountains.

- MEaSUREs data could be used for future estimation of ice thickness over Antarctica, but with cautiousness over areas with slow surface velocities.

- A simple Ice thickness model is used and could be replicated over other mountain areas of Antarctica.

- We found evidence of low advection life cycle of Crevasses over some parts of Union glacier. 


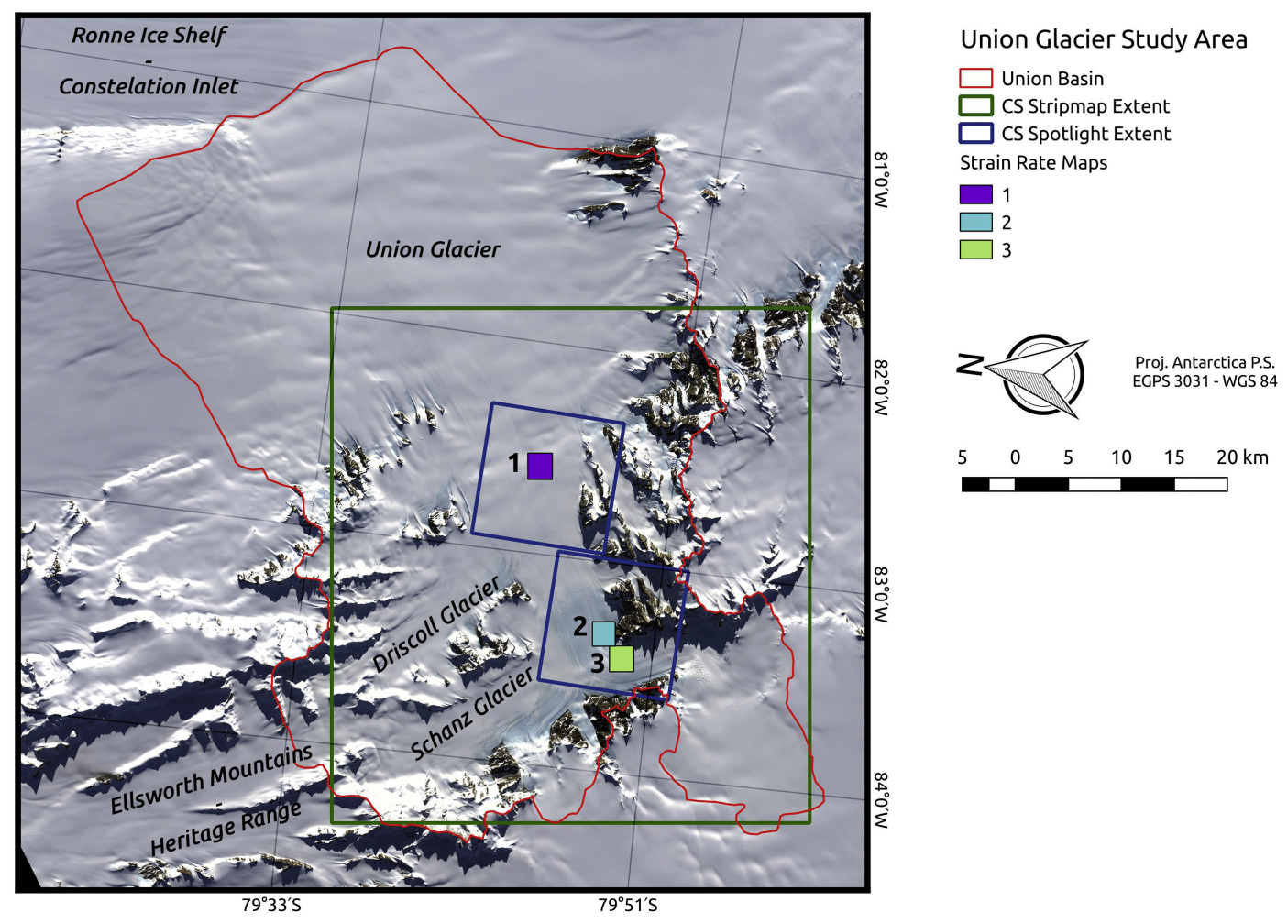

Figure 1 


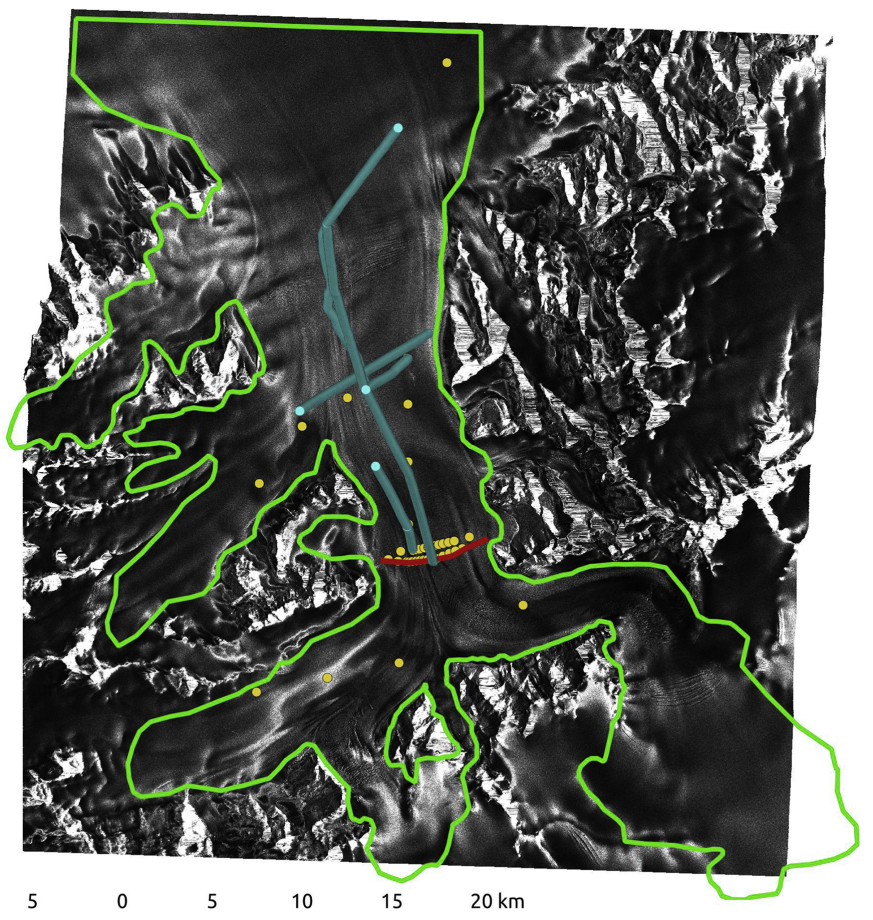

Figure 2 

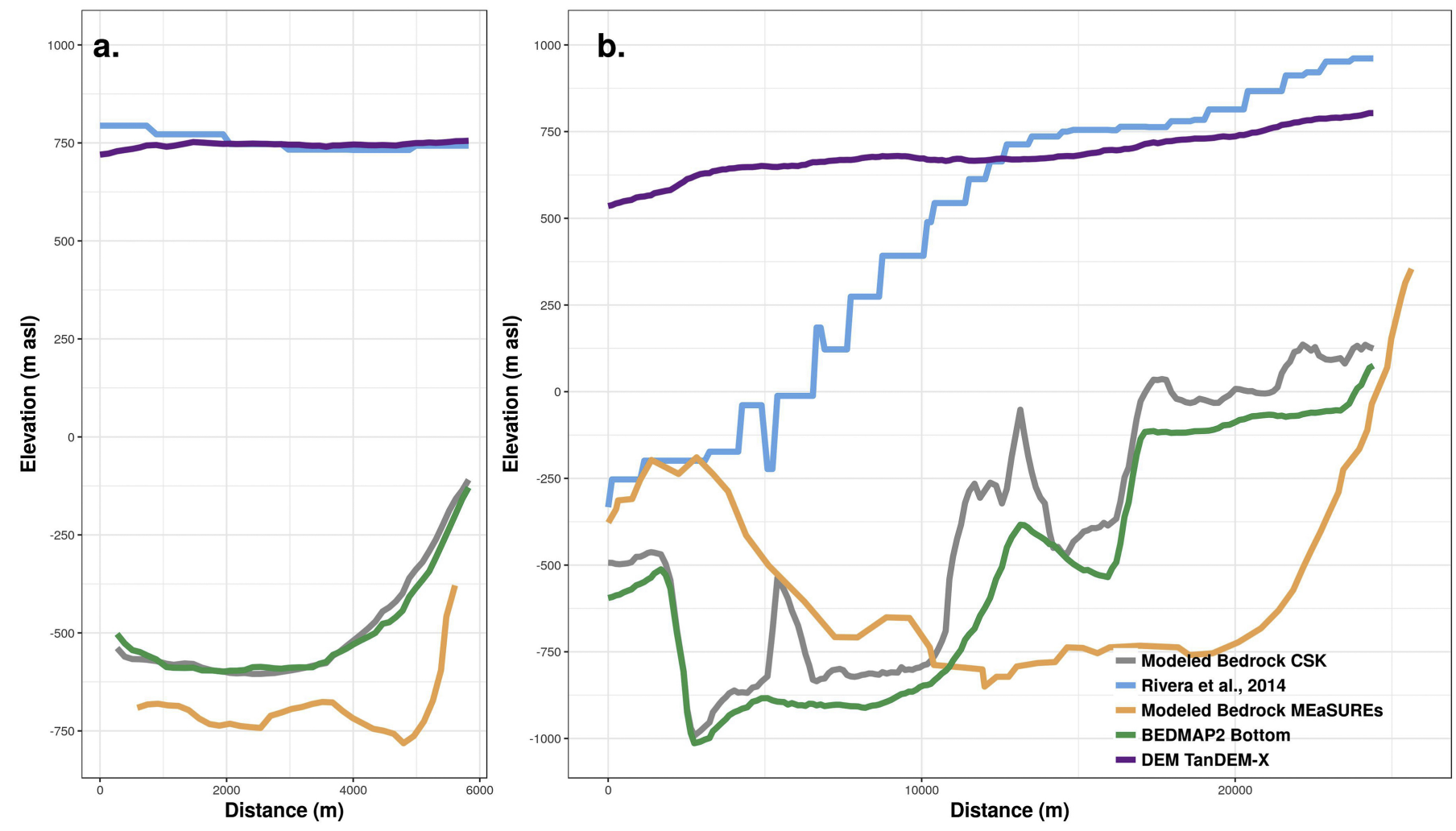

Figure 3 


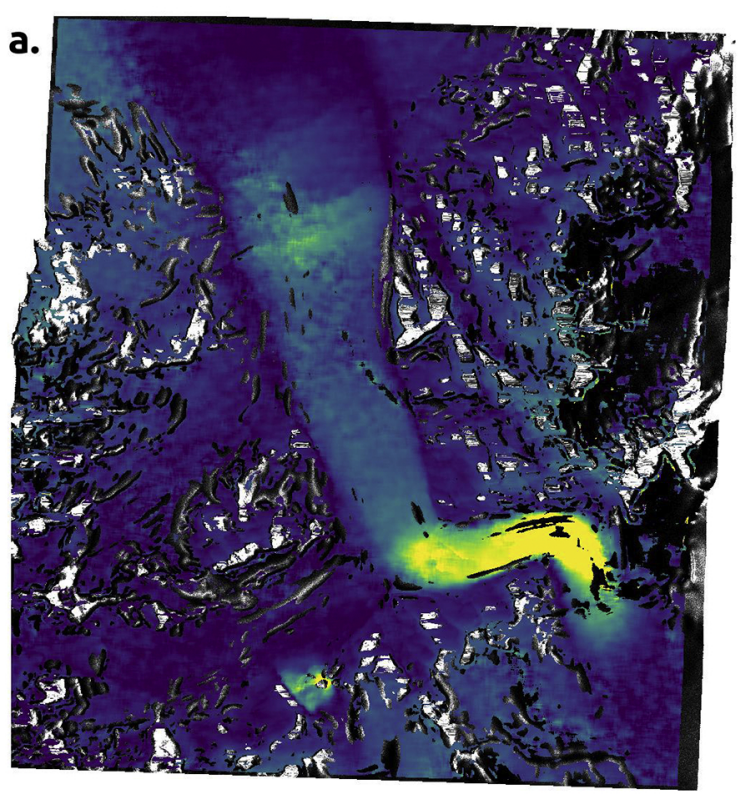

Magnitude of Ice Velocities [m d ${ }^{-1}$ ]

0.05

0.1

0.15

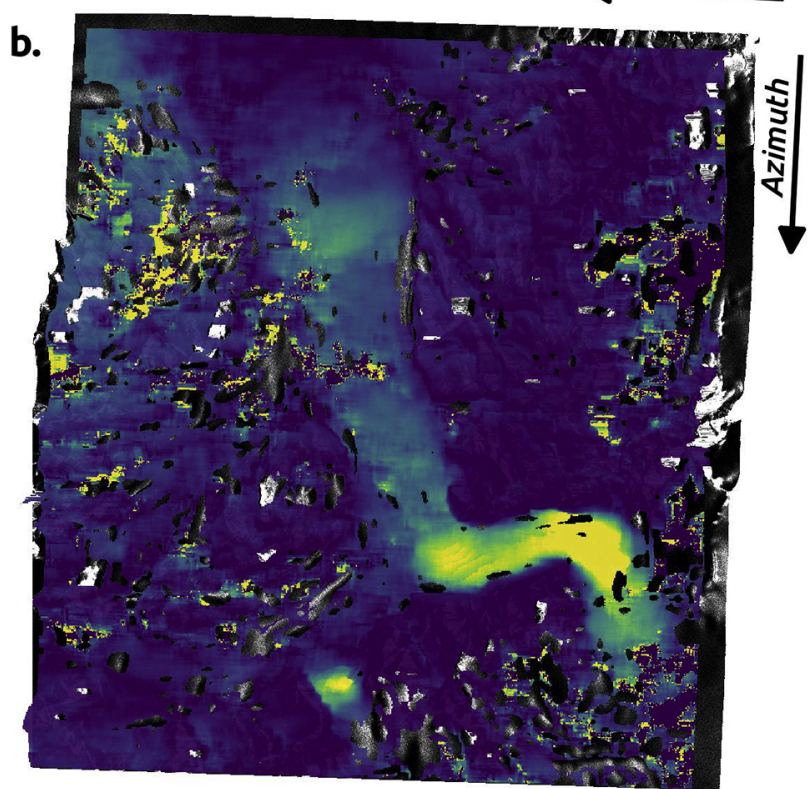

Proj. Antarctica P.S.

EPGS 3031 - WGS 84

$\begin{array}{llllll}2.5 & 0 & 2.5 & 5 & 7.5 & 10 \mathrm{~km}\end{array}$

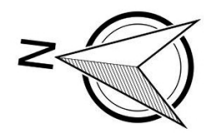

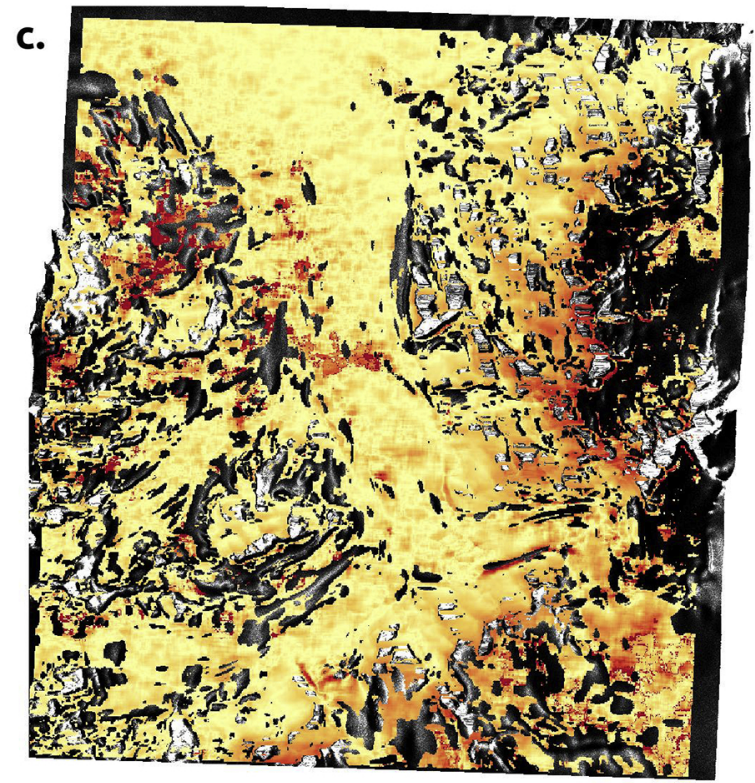

Difference Pair 1 - Pair2 [m d-1]

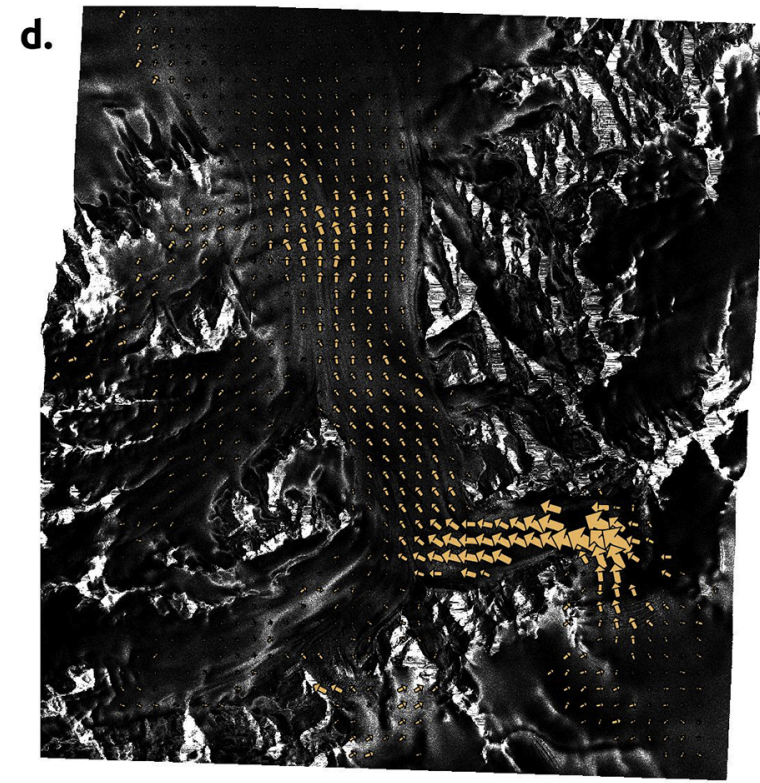

§ Ice flux direction 

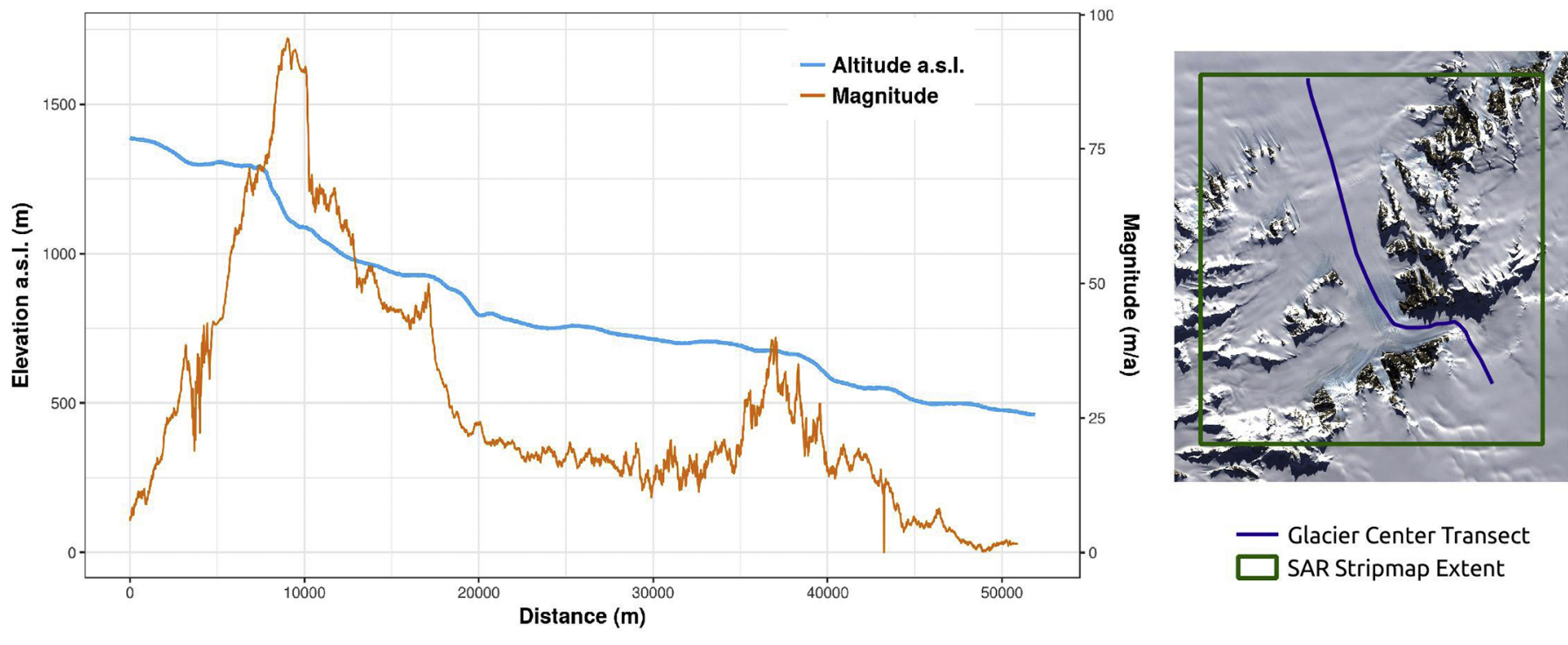

Figure 5 

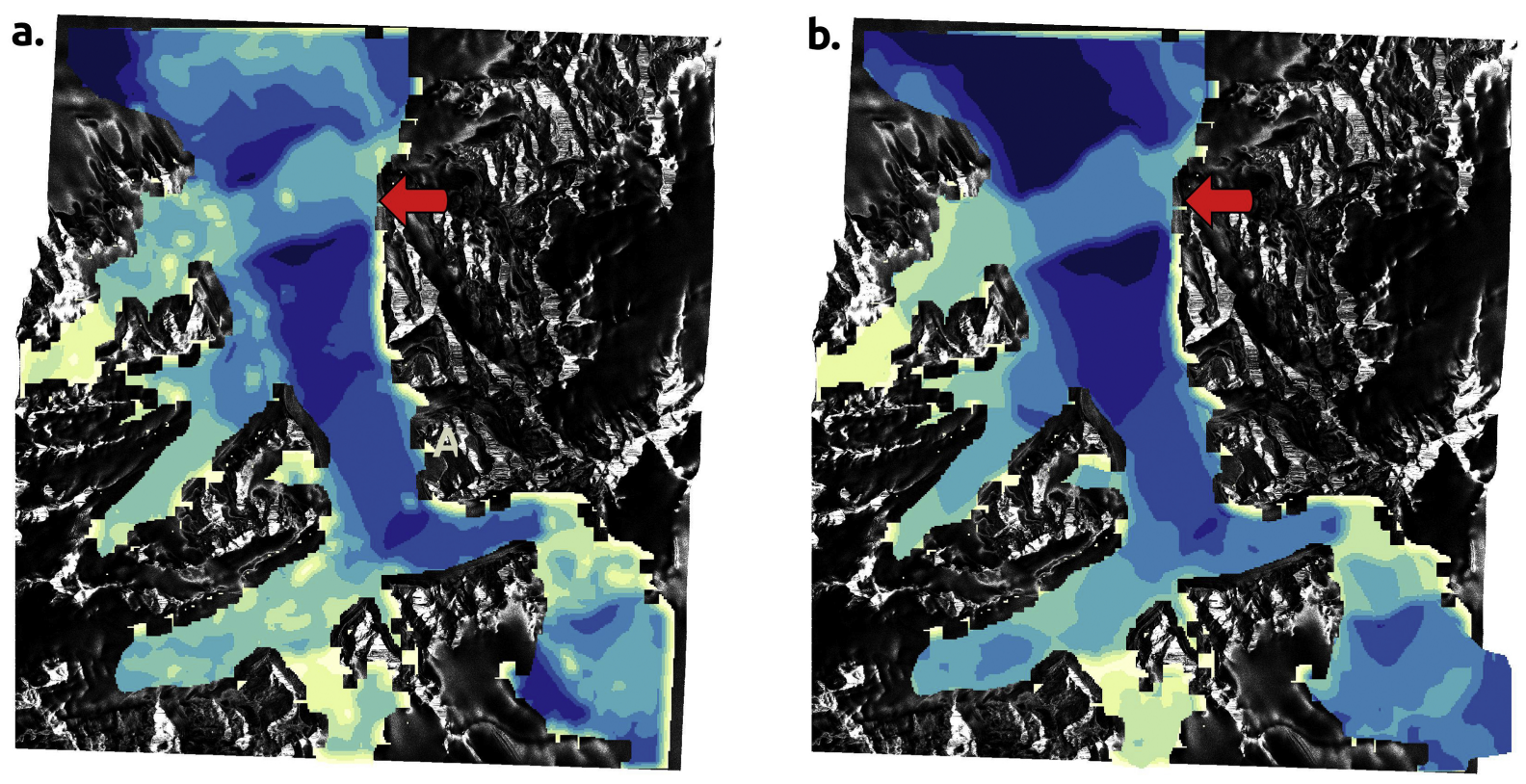

Ice thickness in meters

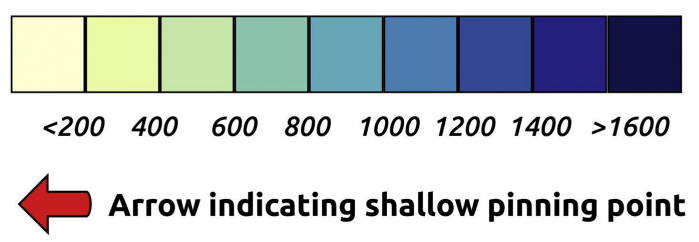

Proj. Antarctica P.S. EPGS 3031 - WGS84 


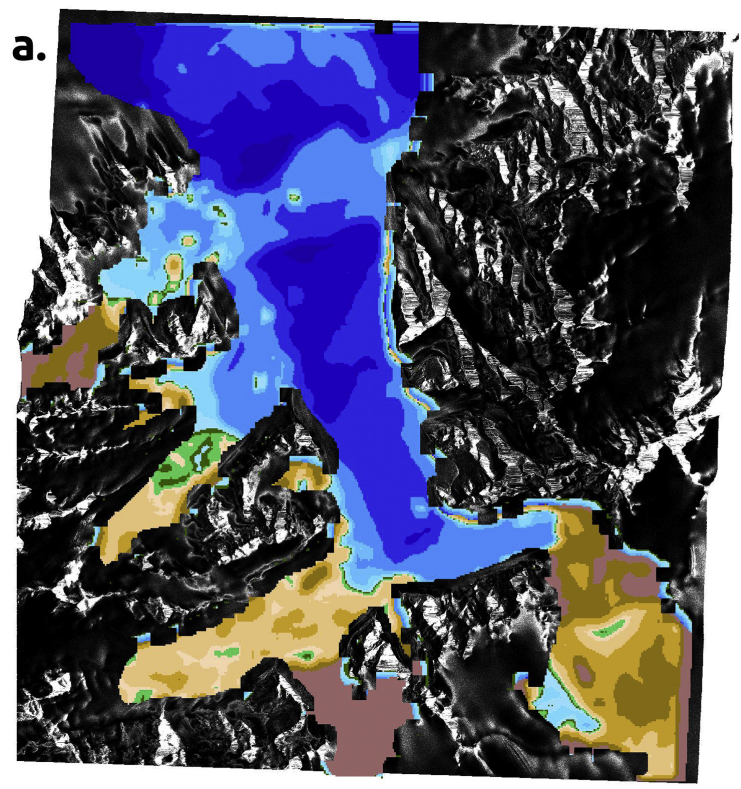

Bedrock a.s.l in meters

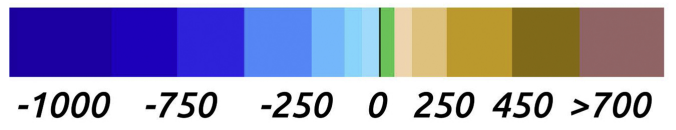

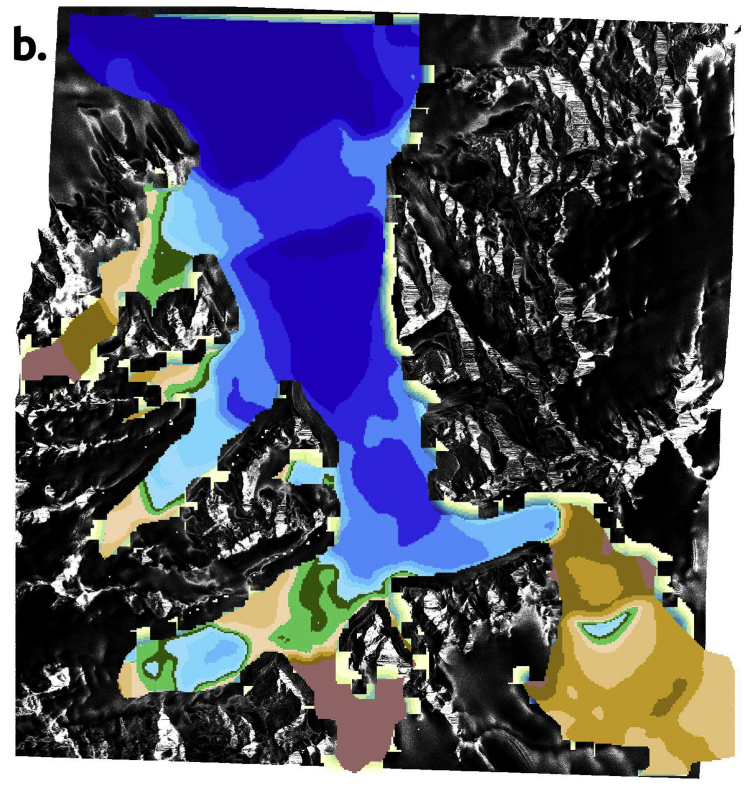

Proj. Antarctica P.S. EPGS 3031 - WGS 84

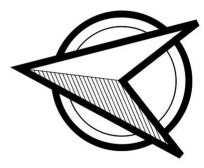

$\begin{array}{llllll}2.5 & 0 & 2.5 & 5 & 7.5 & 10 \mathrm{~km}\end{array}$ 


\section{a.}
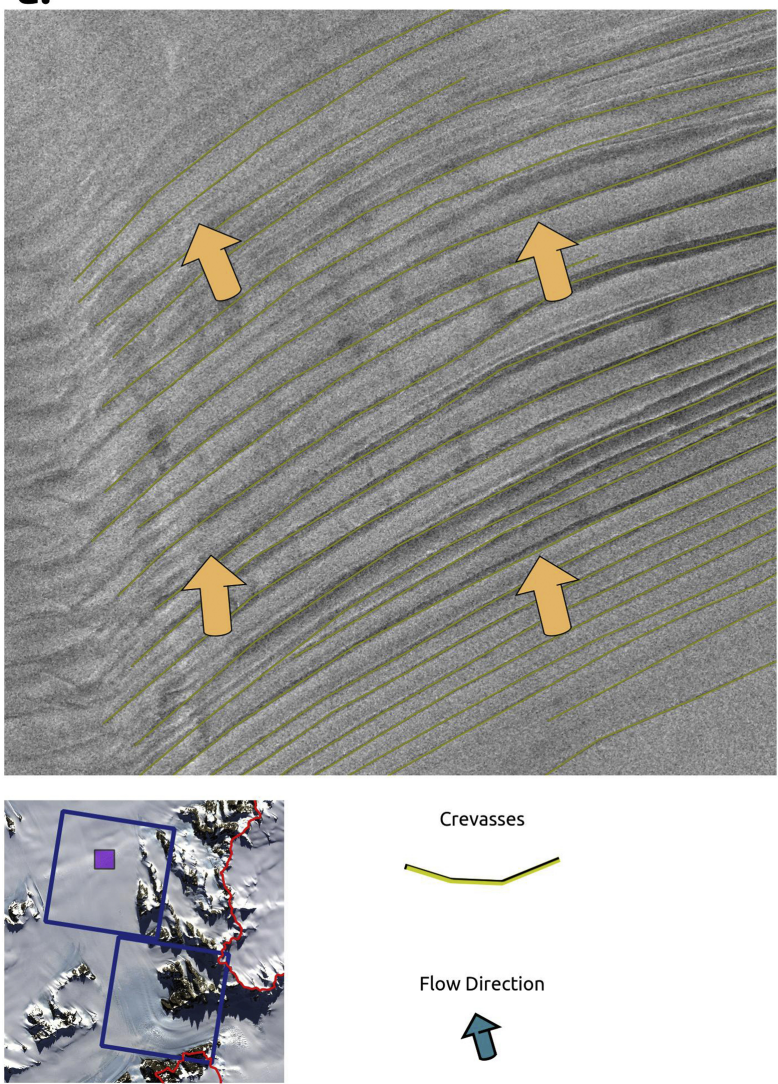

Crevasses

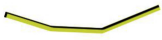

Flow Direction

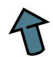

b.

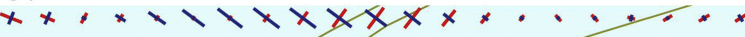

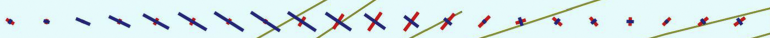

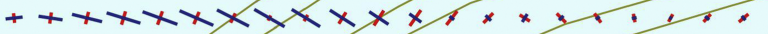

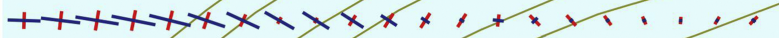

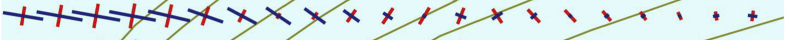

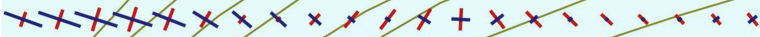

$x \times x \times x+1,1, x \times x+x x+x+x$ $x>1+1+1+x \times x \times x \times x \times x \times x$ $x \times 1++1+1+1+1+x \times x \times x \times x$ $x+x+x+4+4+4 \times x \times x \times x$

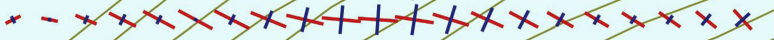
$+x \times x \times x \times+4+x+x+x+x$ $+x \times \times \times x \times x \times 4 \times x \times 1$ $+x \times \times \times \times \times \times \times x+x \times x+x$ $+x \times x \times x \times x \times x+x+x+x$ $+x \times x \times x \times x \times x+x+x$

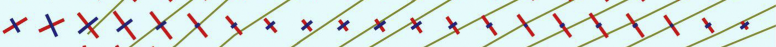

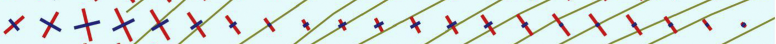

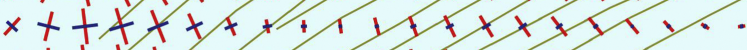

$x+t+t+4+1+17+x+x+\ldots$

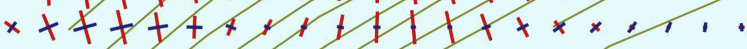

Extending Strain Rate 0,03 year $^{-1}$
Compressing Strain Rate $-0,03$ year $^{-1}$
200
$200 \quad 400$

600

80

Antarctic Polar Sterographic Projection

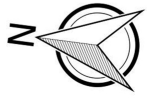

Figure 8 
a.
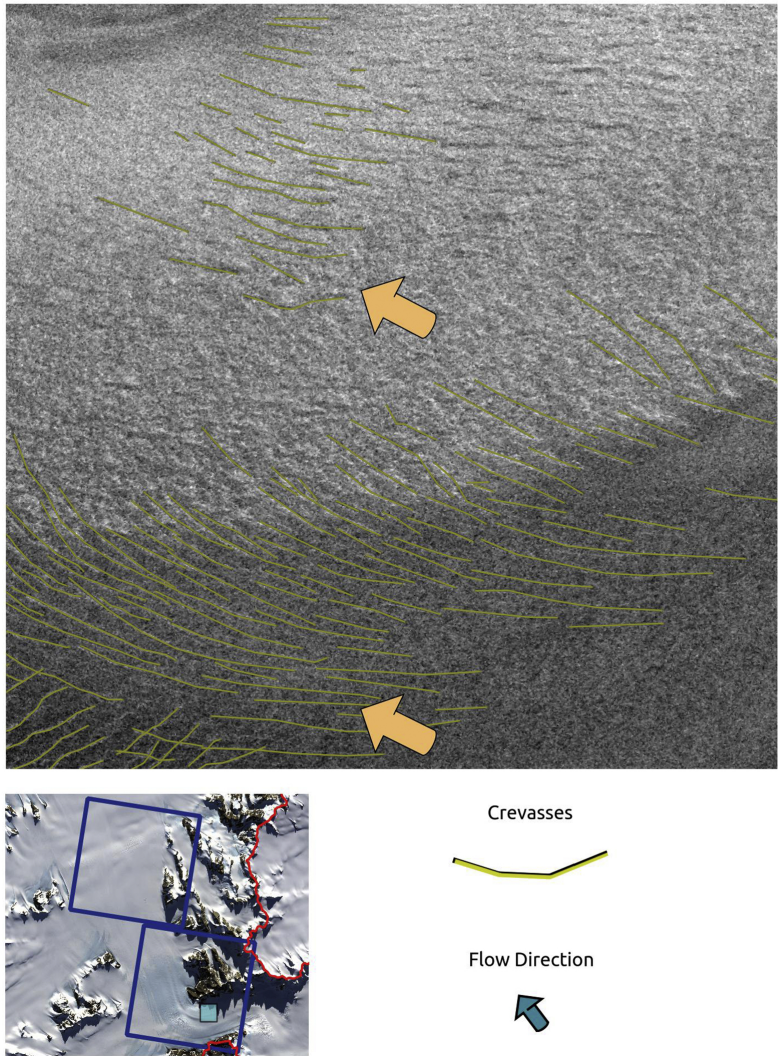

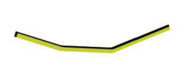

Flow Direction

原

b.

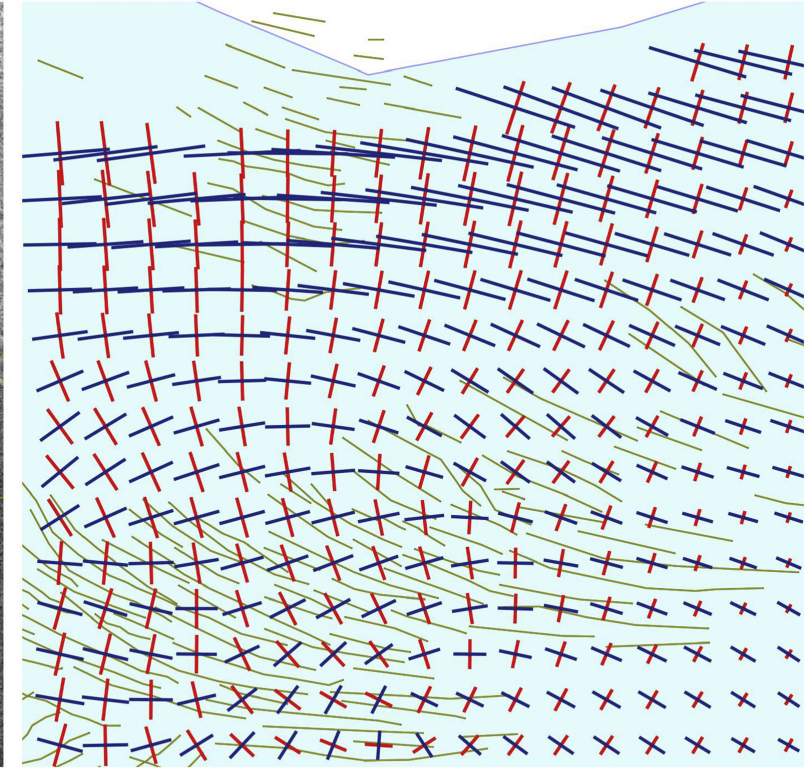

Extending Strain Rate 0,03 year $^{-1}$
Compressing Strain Rate $-0,03$ year $^{-1}$

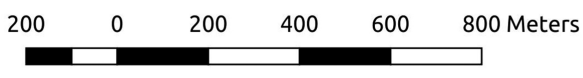

Antarctic Polar Stereographic Projection

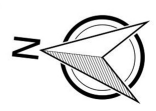

Figure 9 
a.
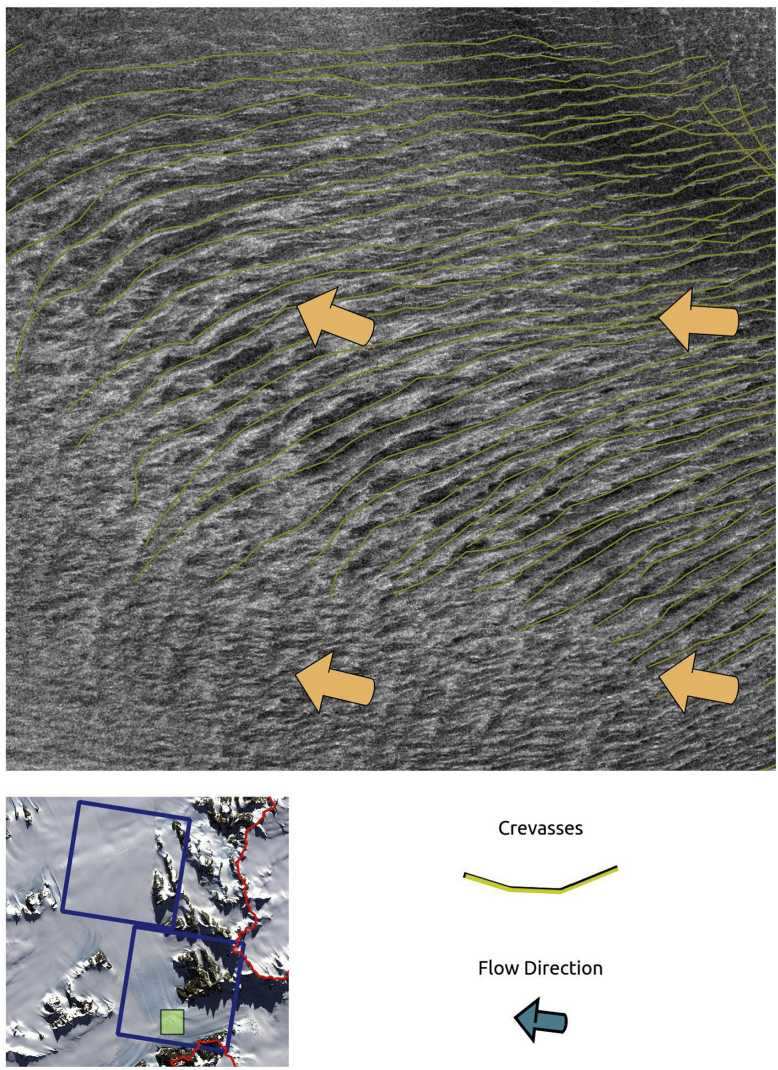

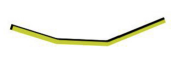

Flow Direction

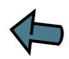

b.

$x \times x>x-x=x=0$ $x+t+t+$

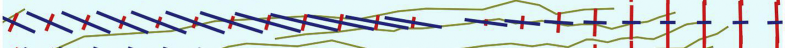

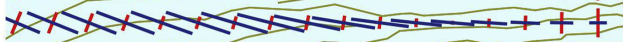

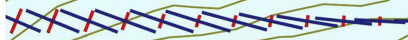

$x<x<x<x=0 \div$

$+t+t+t$

$x>x x \rightarrow \cdots+\ldots+t+7 \neq=$

$x \times<\times>\rightarrow+x+t+x+7++7+7=$ $x \times x>3 x+t+t+x+t+t+1+t+1$ $x \times x<x+t+t+t+t+t+t+f+t$ $x \times x-x+t+1+t+t+t+t+t+7$ $x \times y-\infty++1+1+1+1+t+t$ $\cdots+\cdots+1+7+t+t+t+1+1$

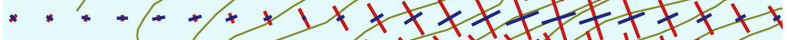

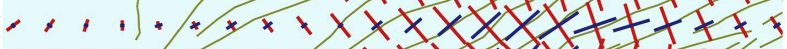

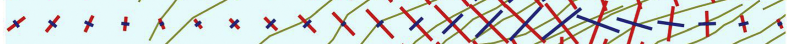
$x \times x+x=x \times x \times x \times x+x+10$ $x \times x \times+x-x \times x>1+t+74+11 \times x$ $x \times x \times++x-x \times x \times+1+1+x \times 1+x$ $x \times x+y+1+x-x+x+1+1+x+1$ $x+1=1=1+-1+x+1+1+2+++$ $t=1-1=1-1+x \times 111+x+\cdots++4$
Extending Strain Rate 0,03 year $^{-1}$

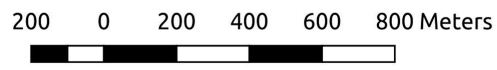

Antarctic Polar Stereographic Projection
Compressing Strain Rate $-0,03$ year ${ }^{-1}$

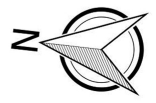

Figure 10 


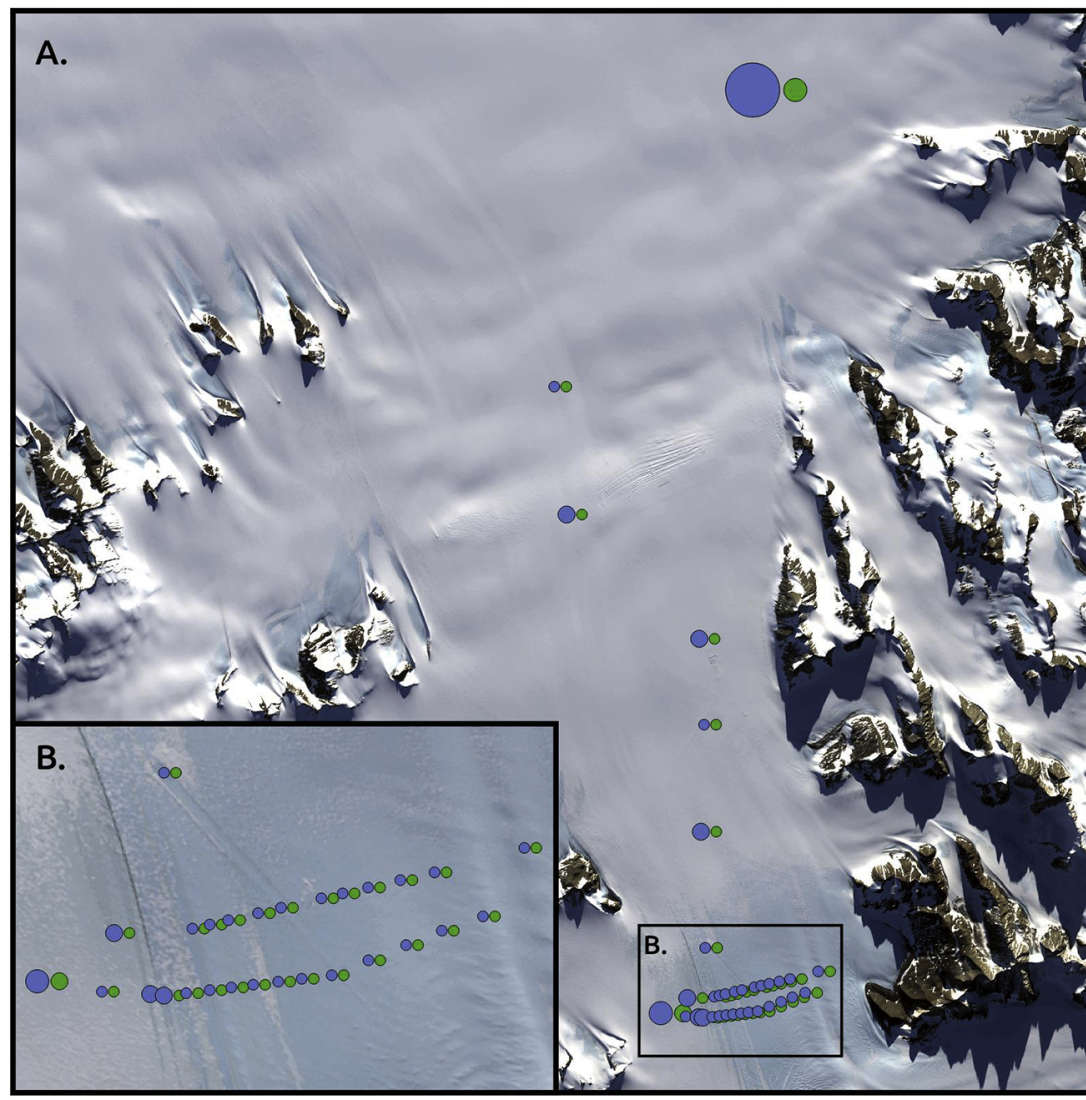

\% Difference of Velocities

Ground points and CSK pair 1

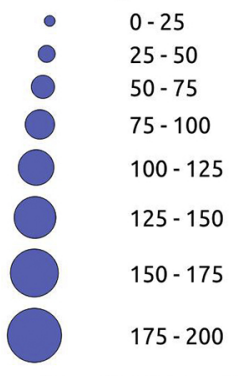

Ground points and MEaSUREs

- $0-25$

- $25-50$

1. $50-75$

$75-100$

$100-125$

(25-150

○150-175

$175-200$

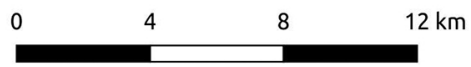

Antarctic Polar Stereographic Projection

Figure 11 


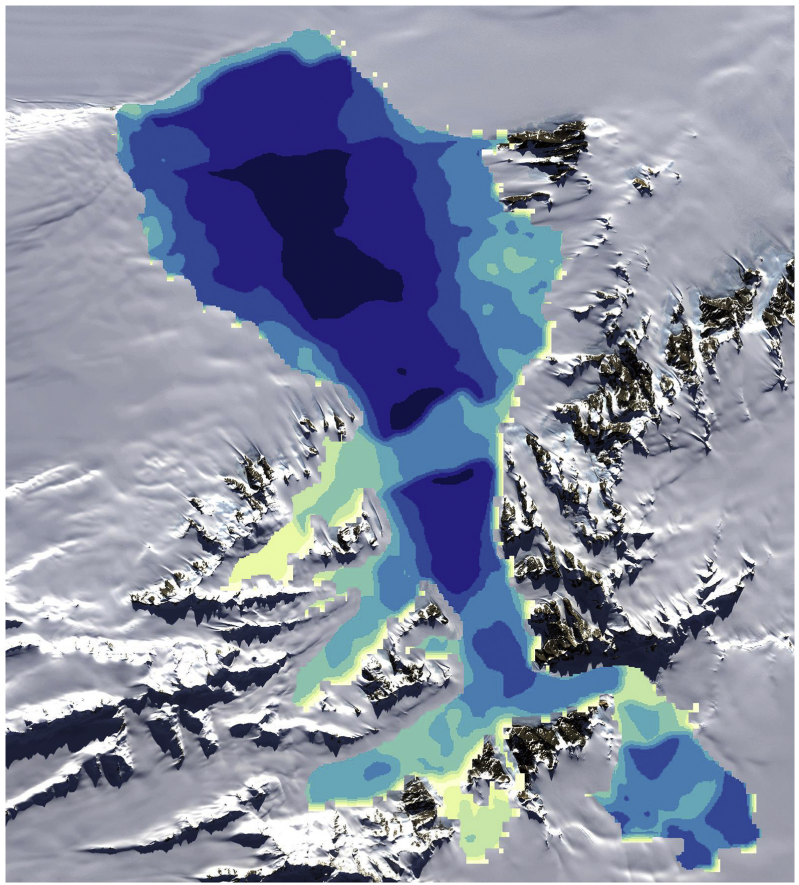

\section{Ice thickness in meters}

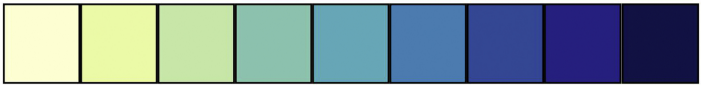

$<200400600800 \quad 100012001400>1600$

Proj. Antarctic Polar $2.502 .557 .510 \mathrm{~km}$ Stereographic
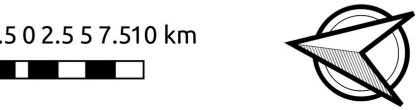

Figure 12 
a.

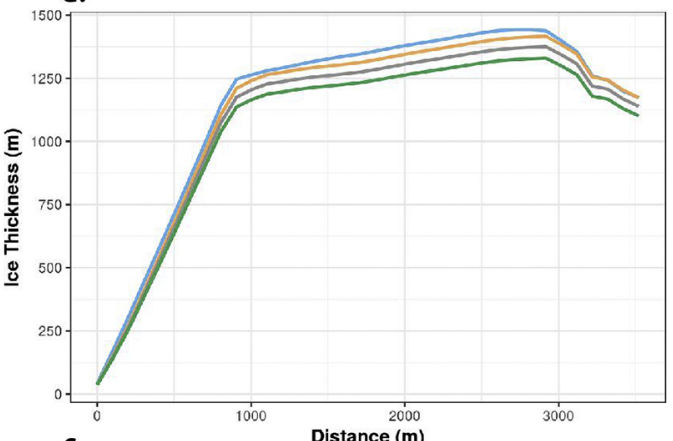

c.

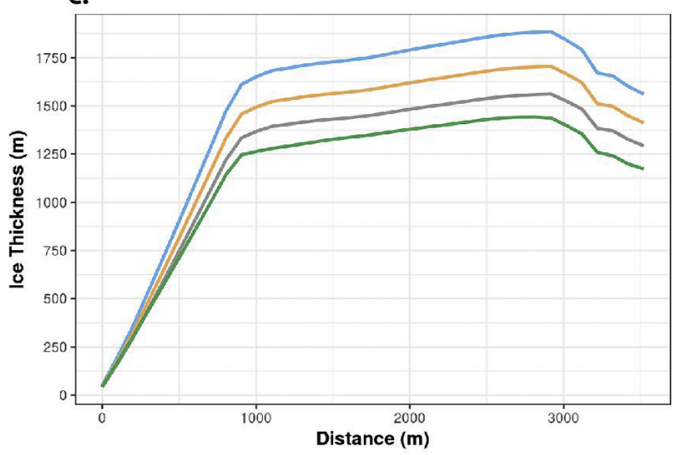

b.

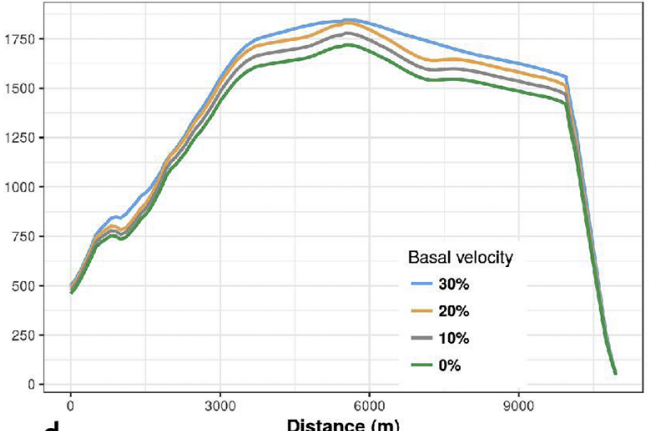

d.

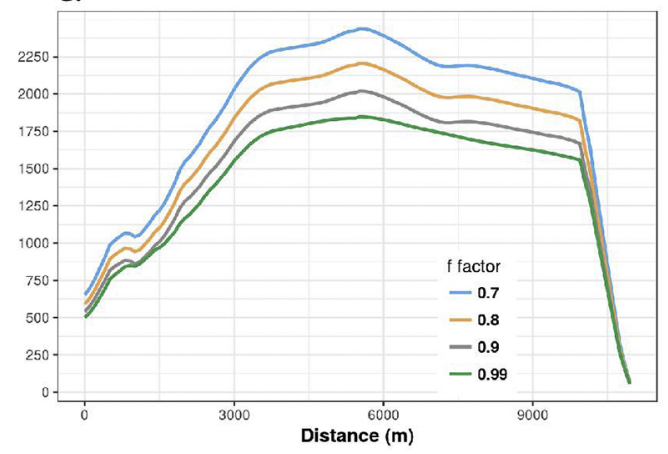

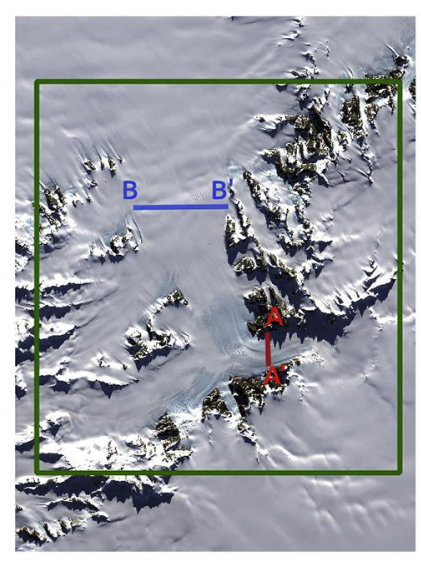

- A-A'

B-B'

$\square$ SAR Stripmap Extent 